\title{
Taxonomic revision of Pseudolaelia Porto \& Brade (Laeliinae, Orchidaceae) ${ }^{1}$
}

\author{
Luiz Menini Neto ${ }^{2,5}$, Rafaela Campostrini Forzza ${ }^{3}$ and Cassio van den Berg ${ }^{4}$
}

Submitted: 14 September, 2011. Accepted: 7 March, 2013

\begin{abstract}
Pseudolaelia is a genus endemic to eastern Brazil. The species are often epiphytes on Velloziaceae or are saxicolous, predominantly on granitic and gneissic outcrops (inselbergs) in the Atlantic Forest and, less often, in the campos rupestres (dry, rocky grasslands) of the cerrado (savanna) and caatinga (shrublands). The genus is characterized by homoblastic pseudobulbs, long rhizomes, long and usually slender inflorescences, racemes or panicles, bearing pink, yellow or whitish flowers, labellum often 3-lobed, with simple, fimbriate or erose margin, semi-cylindrical or claviform column, cuniculus present. Twelve species are recognized; seven binomials are placed in synonymy. Of those seven, three are considered illegitimate because, contrary to the International Code of Botanical Nomenclature guidelines, there are no corresponding type specimens deposited in a recognized herbarium, and those three were therefore lectotypified. We present descriptions of, illustrations of and a dichotomous key to Pseudolaelia species, as well as addressing their taxonomy, ecology, conservation and geographic distribution.
\end{abstract}

Key words: Eastern Brazil, campo rupestre, conservation, inselberg, taxonomy

\section{Introduction}

Pseudolaelia Porto \& Brade is a member of the subfamily Epidendroideae, tribe Epidendreae, subtribe Laeliinae, and was defined as a monophyletic genus by van den Berg et al. (2000, 2009a). The genus is endemic to eastern Brazil, and its species are predominantly epiphytes on Velloziaceae, or are saxicolous, on quartzite outcrops in the rocky grasslands of the caatinga (shrublands) and of the cerrado (savanna), or on granitic and gneissic outcrops (inselbergs) of the Atlantic Forest, occurring from sea level to elevations of nearly 1500 m (Menini Neto 2011).

The Pseudolaelia genus was established by Porto \& Brade (1935), when they described P. corcovadensis (originating from the state of Rio de Janeiro, supposedly from the Morro do Corcovado-the hill upon which the "concrete Christ", or "Christ the Redeemer", statue stands-in the city of Rio de Janeiro) and transferred Schomburgkia vellozicola Hoehne, described a year earlier by Hoehne (1934), based on a plant from the state of Espírito Santo cultivated in the São Paulo State Orchid House, to the new genus, within which it is now known as P. vellozicola (Hoehne) Porto \& Brade.
Ruschi (1946) established the genus Renata, describing the species $R$. canaanensis Ruschi, and publishing, in the same decade, P. dutrae Ruschi (Ruschi 1949), both from the mountains of the state of Espírito Santo. Pabst (1967) described P. geraensis, based on material from the municipality of Teófilo Otoni, in the state of Minas Gerais. The same author published $P$. irwiniana (from the Planalto de Diamantina), P. cipoensis (from the Serra do Cipó) (Pabst 1973) and P. citrina (from the eastern part of the state of Minas Gerais) (Pabst 1976). Alves (1992) described P. lyman-smithii R.J.V. Alves, which was later synonymized with Epidendrum campestre Lindl. by Barros (2002). Barros (1994) transferred Renata canaanensis to Pseudolaelia, a position that was later supported by molecular analyses (van den Berg et al. 2000; 2009a).

In the last decade, 11 taxa were described: 10 species and one natural hybrid. Of those 11, three are considered illegitimate because there are no corresponding type specimens deposited in a recognized herbarium: P. calimaniorum V.P.Castro \& Chiron; P. oliveirana V.P.Castro \& Marçal; and P. regentii V.P.Castro \& Marçal.

Frey (2003; 2005a; 2005b; 2005c) described four taxa from the state of Espírito Santo: P. brejetubensis and

\footnotetext{
${ }^{1}$ Based on the Doctoral thesis of the first Author

${ }^{2}$ Centro de Ensino Superior de Juiz de Fora, Campus Arnaldo Janssen, Juiz de Fora, MG, Brazil

${ }^{3}$ Jardim Botânico do Rio de Janeiro, Rio de Janeiro, RJ, Brazil

${ }^{4}$ Universidade Estadual de Feira de Santana, Departamento de Ciências Biológicas, Laboratório de Sistemática Molecular de Plantas, Feira de Santana, BA, Brazil

${ }^{5}$ Author for correspondence: menini.neto@gmail.com
} 
P. $\mathrm{x}$ perimii (P. brejetubensis $\mathrm{x} P$. freyi), both from the municipality of Brejetuba; $P$. maquijiensis, from the area surrounding the municipality of Colatina; and P. pavopolitana, from the municipality of Vila Pavão. In addition to these four taxa, Chiron \& Castro Neto (2004) described $P$. freyi, from the municipality of Brejetuba; Castro Neto \& Marçal (2007) described P. regentii, for the south of the state of Bahia; Campacci $(2008 ; 2009)$ described P. pitengoensis, from the municipality of Nova Belém, in the state of Minas Gerais, as well as P. aromatica and P. ataleiensis, from the area surrounding the municipality of Ataléia, also in the state of Minas Gerais; Castro Neto \& Chiron (2009) published P. calimaniorum V.P.Castro \& Chiron and P. oliveirana V.P.Castro \& Chiron, respectively, for the southern and northeastern parts of the state of Espírito Santo.

Barros et al. (2010) listed 16 species for the genus, omitting P. calimaniorum, $P$. oliveirana and the natural hybrid $P$. x perimii Frey from the list; thus, 19 binomials were considered in the beginning of this study, 11 of which were published from 2003 onward.

The aim of this study was to taxonomically revise the species of Pseudolaelia, providing descriptions, a dichotomous key and illustrations, as well as a discussion of the taxonomic and ecological aspects. An additional objective was to describe and provide maps of the geographic distribution and conservation status according to the International Union for Conservation of Nature guidelines (IUCN, 2001).

\section{Material and methods}

Among the following herbaria (acronyms follow Holmgren et al. 1990), there were some that we visited $(*)$, some from which we borrowed material (\#) and some whose pictures or records we analyzed via the Internet $\left({ }^{(}\right)$: the Herbarium of the Federal University of Minas Gerais\# (acronym, BHCB); the Herbarium of the Center for Cacao Research\# (acronym, CEPEC); the Herbarium of the Federal University of Juiz de Fora $^{*}$ (acronym, CESJ); the Herbarium of the Luiz de Queiroz Graduate School of Agriculture ${ }^{\star}$ (acronym, ESA); the Guido Pabst Herbarium* (acronym, GFJP); the Bradeanum Herbarium $^{\star}$ (acronym, HB); the Herbarium of the Federal University of Feira de Santana ${ }^{\star}$ (acronym, HUEFS); the Herbarium of the (Rio de Janeiro) State University of Northern Fluminense* (acronym, HUENF); the Curitiba Municipal Botanical Museum* (acronym, MBM); the Mello Leitão Museum of Biology* (acronym, MBML); the William and Lynda Steere Herbarium of the New York Botanical Garden ${ }^{\circledR}$ (acronym, NY); the Herbarium of the National Museum of Rio de Janeiro* (acronym, R); the Herbarium of the Rio de Janeiro Botanical Garden* (acronym, RB); the Herbarium of the Botanical Institute of São Paulo* (acronym, SP); the University of São Paulo Herbarium of Phanerogamae* (acronym, SPF); the Herbarium of the University of Brasilia\# (acronym, UB); the Herbarium of the (São Paulo) State University at Campinas (acronym, UEC); the Herbarium of Paulista University\# (acronym, UNIP); the
United States National Herbarium ${ }^{\circledR}$ (acronym, US); the Viçosa Herbarium $^{*}$ (acronym, VIC); and the Herbarium of the Federal University of Espírito Santo\# (acronym, VIES). The botanical surveys were carried out between 2007 and 2010. Whenever possible, three type specimens were collected and deposited in the herbaria CESJ, HUEFS and RB. The plants were photographed in the field and a field guide was published (Rapid Color Guide) by The Field Museum, Chicago (available at: http:// fm2.fieldmuseum.org/plantguides/guideimages.asp?ID=455). The selected material was chosen to represent at least one type specimen from each state, with preference to the surveys that were carried out during the study. The maps (Figures 1-3) were prepared using the free access program DIVA GIS 7.1.5, with the Americas Base Map (Bletter et al. 2004). The conservation status of the species was defined according to the categories proposed by IUCN (2001), by means of observations of populations in the field and herbarium data.

\section{Results and discussion}

Pseudolaelia Porto \& Brade, Arq. Inst. Biol. Veg. 2: 209. 1935. Type species: Pseudolaelia corcovadensis Porto \& Brade = Renata Ruschi, Orquid. Nov. Estad. Espírito Santo: 5. 1846.

Herbs epiphyte or saxicolous. Roots filiform, white, usually aerial, apex green in the majority, vinaceous in $P$. canaanensis. Rhizome cylindrical, usually long; cataphylls stramineous, brown, disintegrating into fibers. Pseudobulbs fusiform, rarely pyriform, cross-section cylindrical, frequently sulcate, yellow, green, or vinaceous, homoblastic, stem projection cylindrical, foliate, in $P$. canaanensis cataphylls stramineous, brown, disintegrating into fibers in the oldest ones. Leaves conduplicate, light to dark green, sometimes discolored, abaxial side vinaceous, lanceolate, sometimes linear, erect to patent, sometimes curved, coriaceous, margin serrulate, apex acute. Racemes or panicles (displaying short branches with few flowers or long branches with several flowers), erect, lax, long, thin, frequently pauciflorous, rarely multiflorous, flowers with successive anthesis, several open simultaneously. Flowers pink, yellow or white, rarely cream-colored, maculate or concolorous, resupinate; labellum usually 3-lobed, rarely entire, basally adnate to the column at base; cuniculus present, with coloration similar to the floral parts, visible only in longitudinal section of the column, green and visible only in P. brejetubensis; lateral lobes developed or inconspicuous, median lobes entire, undulate, fimbriate or erose, disk fleshy, usually ornamented with lamella in varying number, with or without trichomes, arranged along the whole disk or only near the base of the median lobe, in some species verrucose at the base of the median lobe; column semicylindrical or clavate, alae near the apex; anther apical, quadrangular; pollinia 8, arranged in two series of 4, yellow, trapezoidal, laterally flattened, caudicle granular. Fruits usually globose, costate, perianth persistent.

Etymology: allusion to the similarity with the genus Laelia for its 8 pollinia. 
Dichotomous key to the species of Pseudolaelia

1. Plant with cylindrical foliate stem projection at the apex of the pseudobulb, bearing 11-19 leaves arranged from the apex of the pseudobulb throughout the projection 4. P. canaanensis 1. Plant without cylindrical foliate stem projection at the apex of the pseudobulb, leaves $2-7$, arranged from the middle to the apex of the pseudobulb.

2. Labellum entire or 2-lobed.

3. Sepals and petals cream-colored, labellum white or white with dark-red stripes, margin fimbriate, disk with several longitudinal lamellae pilose, divergent from the base up to near the apex, flowers odoriferous 1. P. aromatica 3. Sepals and petals yellow, labellum white with vinaceous margin and ribs, margin erose, disk with two lamellae longitudinal divergent, evolving to prominent verrucose ribs near the middle of the labellum, flowers odorless

2. Labellum 3- or 4-lobed.

4. Plants up to $8 \mathrm{~cm}$ in height, excluding the inflorescence

2. P. ataleiensis

4. Plants over $15 \mathrm{~cm}$ in height, excluding the inflorescence.

5. Labellum with isthmus wider than long.

6. Labellum with longitudinal lamellae originating from two basal calli, parallel, forming a median groove, arranged up to near the apex of the median lobe.

7. Plants with rhizome more than $3.3 \mathrm{~cm}$ long, pseudobulbs more than $4.9 \mathrm{~cm}$ long, inflorescence more than $60 \mathrm{~cm}$ long 9. P. geraensis

7. Plants with rhizome no more than $2.6 \mathrm{~cm}$ long, pseudobulbs no more than $3.5 \mathrm{~cm}$ long, inflorescence no more than $45 \mathrm{~cm}$ long 5. P. cipoensis

6. Labellum with longitudinal lamellae arranged from the base up to near the apex of the median lobe. 8. Pseudobulbs with 3-5 lanceolate leaves, inflorescence more than $45 \mathrm{~cm}$ in height 7. P. corcovadensis

8. Pseudobulbs with no more than 3 linear-lanceolate leaves, inflorescence no more than $30 \mathrm{~cm}$ in height

10. P. irwiniana

5. Labellum with isthmus longer than wide.

9. Flowers yellow with median lobe of the labellum vinaceous, lateral lobes of the labellum no more than $2 \mathrm{~mm}$ long. 11.P.pitengoensis

9. Flowers white or pink, lateral lobes of the labellum more than $5 \mathrm{~mm}$ long.

10. Margin of the median lobe of the labellum markedly undulate, cuniculus protuberant, externally green 3. P. brejetubensis 10. Margin of the median lobe of the labellum plain, cuniculus not protuberant, externally with coloration similar to the floral parts.

11. Labellum with the apex of the median lobe frequently rounded, rarely emarginate or apiculate, margin entire, longitudinal lamellae usually glabrous, conspicuous along the entire length of the labellum 12. P. vellozicola

11. Labellum with the apex of the median lobe deeply emarginate, rarely obtuse, margin erose or fimbriate, longitudinal lamellae pubescent, with apex verrucose, standing out near the base of the median lobe 8. P. dutrae

1. Pseudolaelia aromatica Campacci, Colet. Orquídeas Brasil. 7: 246. 2009. Type: Brazil, Minas Gerais, Ataléia, V/2009, Campacci \& Leitão 1964 (Holotype: SP!).

Fig. 4-12.

Herb $20-35 \mathrm{~cm}$ in height. Rhizome $1-6 \mathrm{~cm}$ long, dark to brownish green, cataphylls ovate, ca. $8 \times 5 \mathrm{~mm}$, apex acute. Pseudobulb fusiform, 7-12 cm long, yellow-green, 5 internodes, cataphylls lanceolate, ca. $2-3 \times 2 \mathrm{~cm}$, apex acute. Leaves 3-6, erect, arranged from the middle to the apex of the pseudobulb, lanceolate, $10-25 \times 2-2.5 \mathrm{~cm}$, light green, coriaceous, margin serrulate, apex acute. Panicle ca. 70 $\mathrm{cm}$ long, ca. 110 flowers; peduncle ca. $35 \mathrm{~cm}$ long. Flowers odoriferous, pedicel and ovary ca. $2.5 \mathrm{~cm}$ long; dorsal sepal oblanceolate, ca. $1.4 \times 0.3 \mathrm{~cm}$, cream-colored, concave, margin slightly convolute, apex acute; lateral sepals oblanceolate, ca. $1.3 \times 0.45 \mathrm{~cm}$, cream-colored, asymmetrical, concave, margin slightly convolute, apex acute; petals spatulate, ca. $1.4 \times 0.25 \mathrm{~cm}$, cream-colored, asymmetrical, apex acute; labellum entire, ca. $1 \times 0.8 \mathrm{~cm}$, white or white with dark-red stripes, apical half reniform, margin fimbriate, apex emarginate, disk of the labellum fleshy, with several lamellae longitudinal, pilose, divergent from the base up to near the apex; cuniculus externally inconspicuous; column ca. 5.5 $\mathrm{mm}$ long, base greenish, apex white; anther reddish black; 

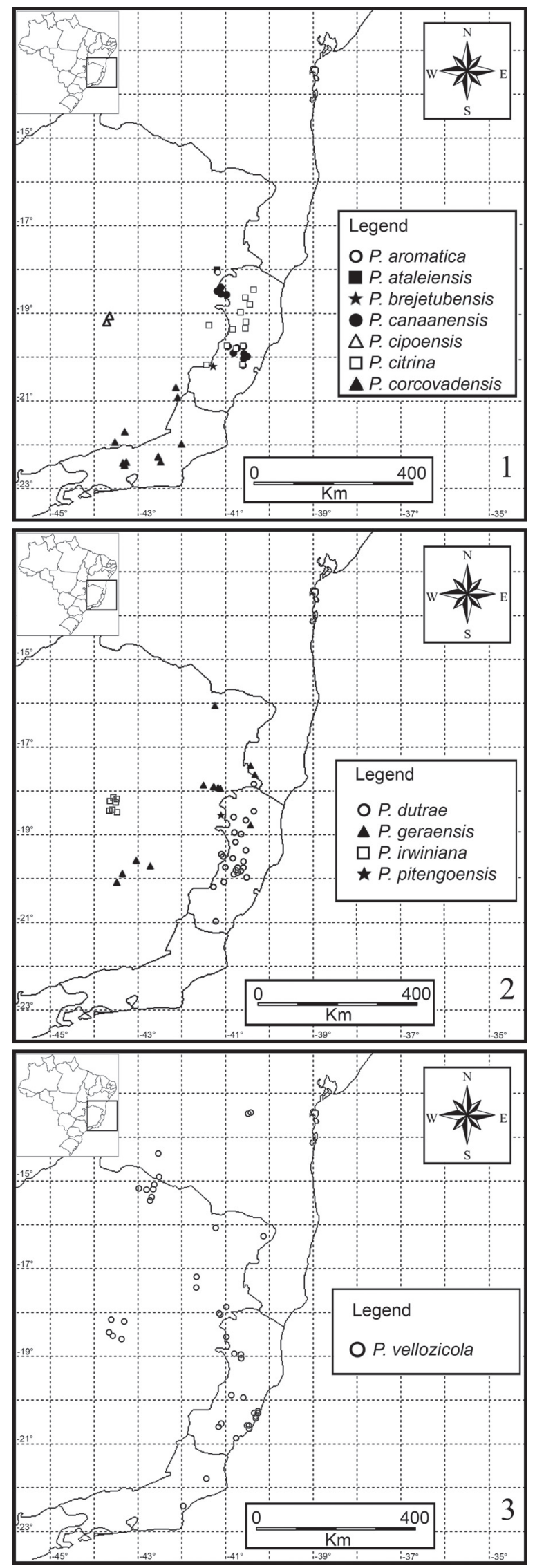

Figures 1-3. Geographic distribution of the species of Pseudolaelia. pollinia ca. $1 \mathrm{~mm}$, caudicle ca. $0.5 \mathrm{~mm}$ long. Fruits not seen. Material examined: type specimen.

Etymology: reference to the odor exuded by the flowers. Geographic distribution and habitat: known only in the type locality. Saxicolous or epiphyte on Velloziaceae on inselbergs at approximately $490 \mathrm{~m}$ above sea level, in the municipality of Ataléia, state of Minas Gerais State (Figure 1).

Conservation status: the only known population is located in an unprotected area, in a region where granite extraction is one of the main economic activities, and the species should therefore be categorized as critically endangered (B2ab(iii)) (IUCN 2001).

Pseudolaelia aromatica is similar to $P$. ataleiensis, but can be differentiated from this and other species by the cream-colored flowers, labellum entire, completely white or white with dark-red stripes, with margin fimbriate and inflorescence in wide panicle, with well-developed secondary branches, in addition to the odor exuded by the flowers, a characteristic that inspired the name and is not observed in any other species of the genus.

2. Pseudolaelia ataleiensis Campacci, Colet. Orquídeas Brasil. 7: 250. 2009. Type: Brazil, Minas Gerais, Ataléia, V/2009, Campacci \& Leitão 1959 (Holotype: SP!).

Fig. 13-21.

Herb $25-35 \mathrm{~cm}$ in height. Rhizome 1-6 cm long, dark to brownish green, cataphylls ovate, ca. $7 \times 4 \mathrm{~mm}$, apex acute. Pseudobulb fusiform, 8-12 cm long, yellowish green, 5 internodes, cataphylls lanceolate, ca. $3.5 \times 2 \mathrm{~cm}$, apex acute. Leaves 3-7, erect, arranged from the middle to the apex of the pseudobulb, lanceolate, $15-25 \times 2-3 \mathrm{~cm}$, light green, coriaceous, margin serrulate, apex acute. Panicle 60-70 $\mathrm{cm}$ long, ca. 120 flowers; peduncle ca. $53 \mathrm{~cm}$ long. Flowers odorless, pedicel and ovary $1.5-2 \mathrm{~cm}$ long; dorsal sepal oblanceolate, ca. $1 \times 0.35 \mathrm{~cm}$, yellow, concave, margin slightly convolute, apex acute; lateral sepals oblanceolate, ca. $9 \times 3$ $\mathrm{mm}$, yellow, asymmetrical, concave, margin slightly convolute, apex acute; petals spatulate, ca. $9 \times 2.5 \mathrm{~mm}$, yellow, asymmetrical, apex acute; labellum entire, ca. $8 \times 9 \mathrm{~mm}$, lobes reniform, ca. $5 \times 5 \mathrm{~mm}$, white with margin vinaceous, erose, apex emarginate; disk of the labellum fleshy, greenish yellow, with two longitudinal divergent lamellae, evolving to prominent verrucose ribs near the middle of the labellum, vinaceous, distributed throughout the lobes; cuniculus externally inconspicuous; column ca. $5 \mathrm{~mm}$ long, yellowish green, with vinaceous shading; anther reddish black; pollinia ca. $1 \mathrm{~mm}$, caudicle ca. $0.5 \mathrm{~mm}$ long. Fruits not seen. Material examined: type specimen.

Etymology: reference to the municipality of Ataléia, state of Minas Gerais, type locality of the species.

Geographic distribution and habitat: the species is known only in the type locality. Saxicolous or epiphyte on Velloziaceae on inselbergs at approximately $280 \mathrm{~m}$ above sea level, in the municipality of Ataléia, state of Minas Gerais (Figure 1). Conservation status: the only known population is located in 
an unprotected area, in a region where granite extraction is one of the main economic activities, and the species should therefore be categorized as critically endangered (B2ab(iii)) (IUCN 2001).

Pseudolaelia ataleiensis bears flowers with similar coloration and slightly similar morphology to those of $P$. canaanensis and $P$. pitengoensis. However, it can be differentiated from $P$. canaanensis by the smaller size and absence of foliate apical projection in the pseudobulb and from $P$. pitengoensis by the larger size and longer inflorescence with larger number of flowers, in addition to the labellum entire (versus 3-lobed with poorly developed lateral lobes).

3. Pseudolaelia brejetubensis M.Frey, Bradea 9(8): 34. 2003. Type: Brazil, Espírito Santo, Brejetuba, Monte Feio, 25/ VI/2001, Frey \& Perim 30 (Holotype: RB!; Isotype: MBML!). Pseudolaelia x perimii M.Frey, Richardiana 5(3): 159. 2005. Type: Brazil, Espírito Santo, Brejetuba, Monte Feio, M.Frey \& L.C.F. Perim 231, 1/V/2002 (Holotype: MBML!), syn nov. Fig. 22-30.

Herb ca. $15 \mathrm{~cm}$ in height. Rhizome $1.5-2 \mathrm{~cm}$ long, green, cataphylls ovate, ca. $5 \times 3 \mathrm{~mm}$, apex acute. Pseudobulb fusiform, ca. $3.5 \mathrm{~cm}$ long, yellowish green to vinaceous, 3-5 internodes, cataphylls lanceolate, ca. $1 \times 0.6 \mathrm{~cm}$, apex acute. Leaves 2-5, curved, arranged from the middle to the apex of the pseudobulb, linear, $10-12 \times 1.2-1.5 \mathrm{~cm}$, discolored, adaxially purplish green, abaxially purple, coriaceous, margin serrulate, apex acute. Panicle $35-40 \mathrm{~cm}$ long, $12-15$ flowers; peduncle $22-25 \mathrm{~cm}$ long. Flowers odorless, pedicel and ovary ca. $1.9 \mathrm{~cm}$ long; dorsal sepal oblanceolate, 1.1-1.4 $\times 0.3-0.4$ $\mathrm{cm}$, white to pink with lines dark pink, slightly concave, apex acute; lateral sepals oblanceolate, $1.1-1.4 \times 0.3-0.4 \mathrm{~cm}$, white to pink with lines dark pink, asymmetrical, concave, apex acute; petals linear-oblanceolate, ca. 1.1-1.4 $\times 0.1 \mathrm{~cm}$, white with apex pink, slightly asymmetrical, apex obtuse; labellum 3-lobed, 0.8-1 ×0.8-1 cm, lateral lobes linear, ca. $4.5 \times 2.5 \mathrm{~mm}$, pink, apex acute, median lobe elliptic, ca. 7 $\times 5 \mathrm{~mm}$, white with lines dark pink, margin markedly undulate, apex obtuse, disk of the labellum fleshy, pilose, with 3-7 lamellae cream-colored from the base up to near the apex of the median lobe; cuniculus green, protuberant, ca. $2 \mathrm{~mm}$ long; column ca. $3 \mathrm{~mm}$ long, purple; anther purple; pollinia ca. $1 \mathrm{~mm}$, caudicle ca. $1 \mathrm{~mm}$ long. Fruits not seen. Material examined: type specimens of $P$. brejetubensis and $P . \mathrm{x}$ perimii, cited above.

Etymology: reference to the municipality of Brejetuba, state of Espírito Santo, type locality of the species.

Geographic distribution and habitat: the species is known only in the type locality, on inselbergs at 1100-1400 $\mathrm{m}$ above sea level, on Monte Feio, municipality of Brejetuba, state of Espírito Santo (Figure 1).

Conservation status: classified as critically endangered in the state of Espírito Santo (Kollmann et al. 2007). The plant was not found during a survey at the type locality and is probably a rare species in the site. Because this species is endemic to the state of Espírito Santo State, it should also be globally categorized as critically endangered (B2ab(iii)) (IUCN 2001). Protection should be planned for this habitat, because its trails are used by motorcyclists, leading to environmental degradation and consequently to the possible extinction of this species.

Pseudolaelia brejetubensis can be differentiated from congeneric species by its white flowers, with sepals and petals longitudinally striped in pink, lateral lobes of the labellum large, with obtuse apex, and medium lobe with margin markedly undulate, in addition to the cuniculus prominent, externally distinct, green. Frey (2005) proposed a natural hybrid between $P$. brejetubensis and $P$. dutrae (the latter categorized by the author as $P$. freyi), and designated it $P$. x perimii, based on the larger size, longer rhizome, intermediate number of branches in the inflorescence, intermediate flowering period and nectary less developed than in $P$. brejetubensis, but still externally observable in the flower. Although the flowers of $P$. x perimii are slightly bigger, the color and floral morphology are practically identical. Furthermore, the presence of the externally distinct green nectary (an important diagnostic characteristic of $P$. brejetubensis), although less developed, confirms that the specimens of $P$. x perimii should be considered within the natural morphological variation in P. brejetubensis. Pseudolaelia brejetubensis and the supposed hybrid were not seen in the field, but the observation of populations of other species and of herbarium material demonstrates that the morphological characters used by Frey (2005) correspond to interpopulation and intrapopulation polymorphism in Pseudolaelia; therefore, $P$. x perimii is synonymized with $P$. brejetubensis.

4. Pseudolaelia canaanensis (Ruschi) F.Barros, Acta Bot. Brasil. 8: 15. 1994. 三 Renata canaanensis Ruschi, Orquid. Nov. Estad. Espírito Santo: 5. 1946. Lectotype designated by Menini Neto et al. (2011): Brazil, Espírito Santo, Santa Teresa, Vale do Canaã, 23/III/1936, Ruschi 46 (R!).

Fig. 31-43.

Herb $20-50 \mathrm{~cm}$ in height. Rhizome $5-13 \mathrm{~cm}$ long, light green, cataphylls ovate to tubular, $0.4-4.1 \times 0.4-0.7 \mathrm{~cm}$, apex acute. Pseudobulb fusiform, 6-36 cm long, yellowish green, 5-8 nodes, apex with stem projection foliate cylindrical, 8.5$15.3 \mathrm{~cm}$ long, partially intumesced with cataphylls ovate to lanceolate, $1.7-4.1 \times \mathrm{ca} .1 .5 \mathrm{~cm}$, apex obtuse to acute. Leaves 11-19, patent, arranged from the apex of the pseudobulb, throughout the stem projection, linear to lanceolate, 1.5-19.5 $\times 0.7-3.1 \mathrm{~cm}$, light green, chartaceous, margin finely serrulate to entire, apex acute. Panicle $37-70 \mathrm{~cm}$ long, branches of the inflorescence $6-15.5 \mathrm{~cm}$ long, ca. 90 flowers; peduncle $34-50 \mathrm{~cm}$ long. Flowers odorless, pedicel and ovary 1.1-1.6 $\mathrm{cm}$ long; dorsal sepal oblanceolate, ca. $1 \times 0.3 \mathrm{~cm}$, light yellow, margin convolute near the apex, with a thickened region, slightly verrucose, brown, apex acute; lateral sepals oblanceolate, ca. $1.1 \times 0.3 \mathrm{~cm}$, asymmetrical, light yellow, 




Figures 4-30. Pseudolaelia aromatica Campacci: 4. General aspect; 5. General view of the flower; 6. Dissected perianth; 7. Column, lateral view; 8. Column, longitudinal section; 9. Column, ventral view; 10, Anther, ventral view; 11. Anther, dorsal view; 12. Isolated pollinium (4-12: Campacci 1964). Pseudolaelia ataleiensis Campacci: 13. General aspect; 14 . General view of the flower; 15 . Dissected perianth; 16. Column, lateral view; 17. Column, longitudinal section; 18 . Column, ventral view; 19, Anther, ventral view; 20. Anther, dorsal view; 21. Isolated pollinium (13-21: Campacci 1959). Pseudolaelia brejetubensis M.Frey: 22. General aspect; 23. General view of the flower; 24 . Dissected perianth; 25. Column, lateral view; 26. Column, longitudinal section; 27 . Column, ventral view; 28. Anther, dorsal view; 29. Anther, ventral view; 30. Isolated pollinium (22-30: Frey 30). 
margin convolute near the apex, with a thickened region, slightly verrucose, brown, apex acute; petals spatulate, ca. $1.1 \times 0.3 \mathrm{~cm}$, light yellow, asymmetrical, margin slightly undulate near the acute apex; labellum entire, ca. $7 \times 5$ $\mathrm{mm}$, margin erose, apex rounded or emarginate; disk of the labellum fleshy, with lamellae longitudinal, divergent, irregular, light yellow to gold yellow, sometimes with the apex maculate in red, from the base up to near the apex of the labellum; cuniculus externally inconspicuous; column ca. 5-7 mm long, yellowish green; anther reddish black; pollinia ca. $1 \mathrm{~mm}$, caudicle ca. $1 \mathrm{~mm}$ long. Fruits globose, ca. $1 \mathrm{~cm}$ long, dark green.

Material selected: BRAZIL. Espírito Santo: São Roque do Canaã, Misterioso, Pedra dos Três Carneiros, 1/VIII/2008, fl., Menini Neto \& Fontana 614 (CESJ, RB). Minas Gerais: Nova Belém, Serra do Pitengo, 30/V/2009, fl. fr., Menini Neto et al. 761 (CESJ, HUEFS, RB).

Etymology: reference to the Vale do Canaã, state of Espírito Santo, type locality of the species.

Geographic distribution and habitat: the species occurs on the inselbergs of the mountainous region, in the northwestern and northern parts of the state of Espírito Santo and eastern part of the state of Minas Gerais (Figure 1), at 550-1300 m above sea level. It forms large populations with many saxicolous individuals among mosses and lichens. Conservation status: classified as vulnerable in the state of Espírito Santo (Kollmann et al. 2007) and in Brazil as a whole (Biodiversitas 2005); listed as data deficient on the Brazilian Ministry of the Environment list of endangered species (MMA, 2008), as well as on the list of the rare plants of Brazil (van den Berg et al. 2009b). The inclusion of this species on the aforementioned lists is due to the fact that it was long considered endemic to the Vale do Canaã, municipality of Santa Teresa, state of Espírito Santo. However, several surveys carried out in the last ten years have increased the knowledge of its geographic distribution, which is now known to include the eastern part of the state of Minas Gerais. Therefore, this species should be globally categorized as least concern (IUCN 2001).

Pseudolaelia canaanensis was described in the genus Renata by Ruschi (1946), and was later transferred to Pseudolaelia by Barros (1994). Although its floral morphology is similar to that of $P$. aromatica and $P$. ataleiensis, it can be easily differentiated from the other species of Pseudolaelia by the more robust appearance, greater number of leaves (11-19), the stem projection at the apex of the pseudobulb, with leaves distributed throughout, and by the inflorescence in wide panicle, usually with more than 80 small flowers, light yellow to gold yellow, the labellum spotted with red in some specimens.

5. Pseudolaelia cipoensis Pabst, Bradea 1:365. 1973. Type: Brazil, Minas Gerais, Serra do Cipó, 15.V.1970, Ghillany 209 (Holotype: HB!).

Fig. 44-54.
Herb 15-20 cm in height. Rhizome ca. 2-2.6 cm long, green to vinaceous, cataphylls ovate, apex acute. Pseudobulb fusiform, ca. 2.3-3.4 cm long, green, 3-4 internodes, apex acute. Leaves 4 , erect, arranged from the middle to the apex of the pseudobulb, lanceolate, $8.3-12.6 \times 0.7-1 \mathrm{~cm}$, green, coriaceous, margin serrulate, apex acute. Raceme or panicle, the latter with only one branching, ca. 30-45 cm long, 6-12 flowers; peduncle ca. $25-46 \mathrm{~cm}$ long. Flowers odorless, pedicel and ovary ca. 1.3-1.7 cm long; dorsal sepal elliptic, 8-9 × ca. 4 $\mathrm{mm}$, pink, apex acute; lateral sepals elliptic, 1-1.1 $\times$ ca. 0.5 $\mathrm{cm}$, pink, slightly asymmetrical, concave, apex acute; petals obovate, 7.5-8 $\times$ 5-6 mm, pink, asymmetrical, apex acute; labellum 3-lobed, ca. $8 \times 8 \mathrm{~mm}$, lateral lobes elliptic, ca. 2 $\times 1 \mathrm{~mm}$, pink, apex rounded, median lobe suborbicular, ca. $6 \times 8 \mathrm{~mm}$, pink with lines dark pink, apex rounded, disk of the labellum fleshy, with 3 lamellae yellow from the base up to the beginning of the median lobe; cuniculus externally inconspicuous; column ca. $5 \mathrm{~mm}$ long, pink; anther dark pink; pollinia ca. $1 \mathrm{~mm}$, caudicle ca. $1 \mathrm{~mm}$ long. Fruits not seen.

Material selected: BRAZIL. Minas Gerais: Santana do Riacho, Pico do Breu, 15/VII/1991, fl., Pereira et al. 893 (BHCB).

Etymology: reference to the Serra do Cipó, state of Minas Gerais, type locality of the species.

Geographic distribution and habitat: the species is known only from a few records at the Serra do Cipó (Figure 1), at an elevation of nearly $1400 \mathrm{~m}$ above sea level, occurring as an epiphyte on Velloziaceae. It appears to be quite rare in this region; despite three decades of intensive study of the flora of the Serra do Cipó, the species was collected only three times since its publication in the decade of 1970. The species was not found in two surveys conducted at this locality, which reinforces the hypothesis of rarity in the area. Conservation status: classified as vulnerable in Brazil (Biodiversitas 2005) and critically endangered in the state of Minas Gerais, because of the extreme endemism (Biodiversitas 2007). It is also on the official list of endangered species in Brazil (MMA 2008). Because of the scarcity of records since its publication and the likelihood that its area of occupancy has been reduced, this species should be categorized as vulnerable (D2), according to the IUCN criteria (IUCN 2001).

Pseudolaelia cipoensis has the greatest affinity with $P$. geraensis and $P$. irwiniana. It can be differentiated from the first by the smaller size and shorter inflorescence, the presence of 4 leaves by pseudobulb (vs. 4-7) and the narrower lateral lobes of the labellum, that stand out from the median lobe ( $v s$. lateral lobes larger, usually overlapping the median lobe). It can be differentiated from $P$. irwiniana by its larger size, the presence of 4 leaves by pseudobulb ( $v s .2$ or 3 leaves) and inflorescences with fewer flowers, more evenly distributed ( $v s$. flowers more tightly grouped at the apex), labellum with lamellae that originate from two basal calli, parallel and forming a median groove, arranged up to near the apex of the median lobe ( $v s$. lamellae that originate from the base of the labellum up to near the apex of the median lobe). 

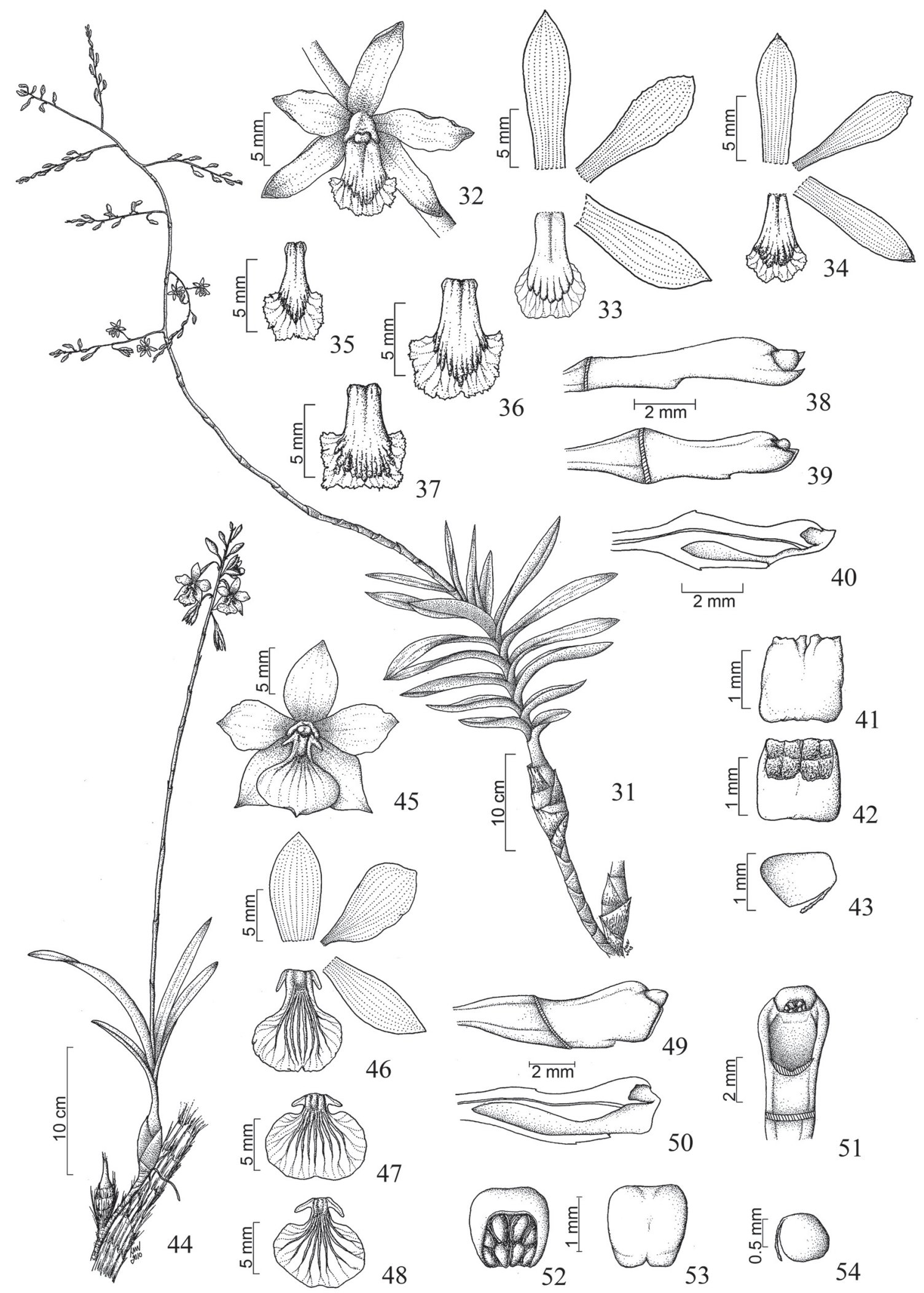

37
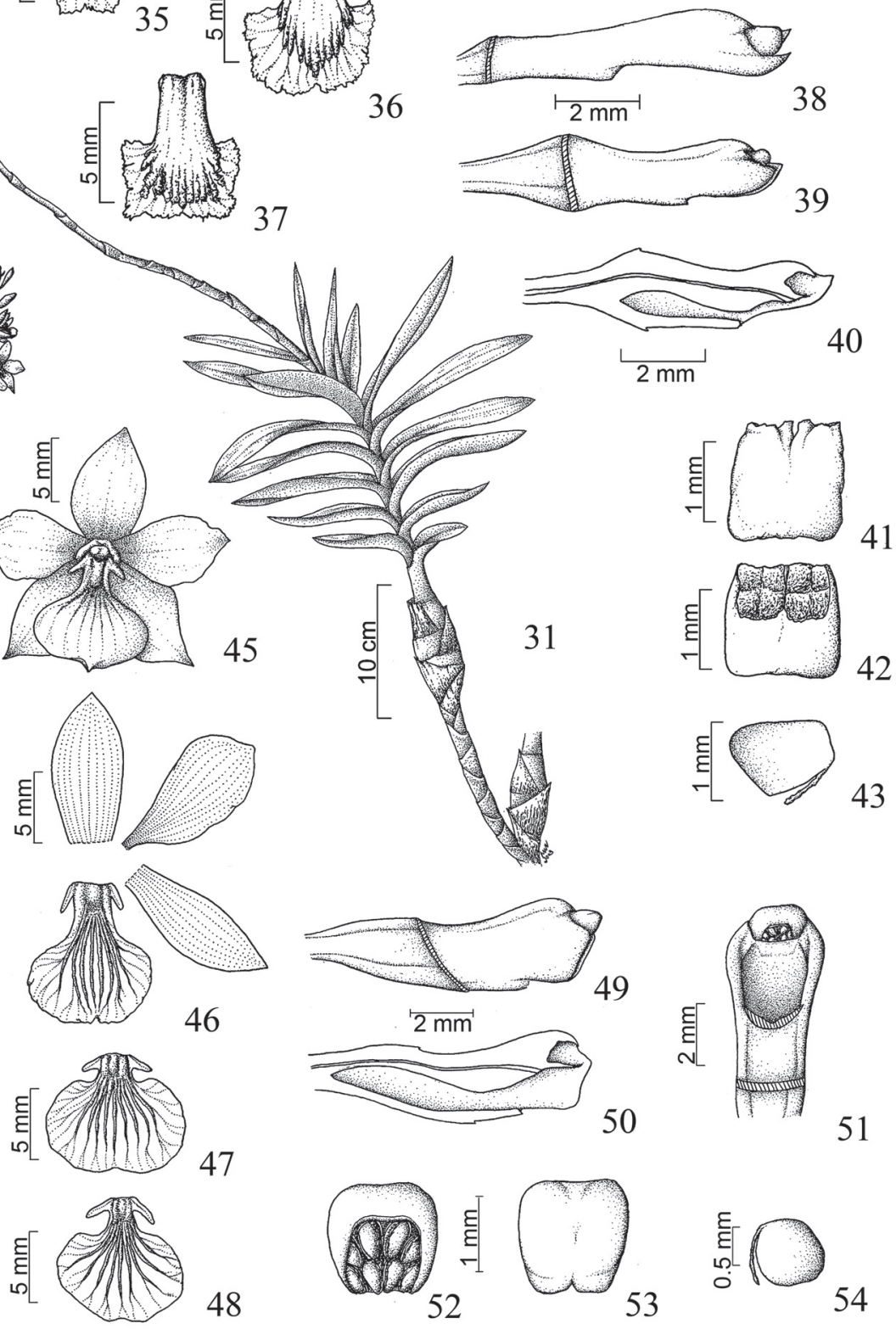

\section{8}
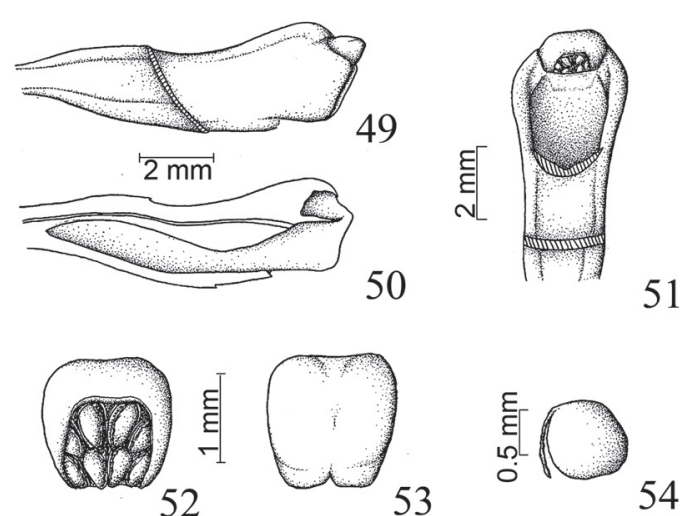

Figures 31-54. Pseudolaelia canaanensis (Ruschi) F.Barros: 31. General aspect; 32. General view of the flower; 33-34. Dissected perianth; 35-37. Details of the labellum; 38-39. Column, lateral view; 40. Column, longitudinal section; 41. Anther, dorsal view; 42. Anther, ventral view; 43. Isolated pollinium (31-32, 37, 39, 40: Menini Neto 475; 33, 38: no colector (MBML 22844); 34, 41-43: Ruschi s.n. (SP 55328); 35: Fontana 5052; 36: Menini Neto 761). Pseudolaelia cipoensis Pabst: 44. General aspect; 45. General view of the flower; 46. Dissected perianth; 47-48. Details of the labellum; 49. Column, lateral view; 50 . Column, longitudinal section; 51. Column, ventral view; 52, Anther, ventral view; 53. Anther, dorsal view; 54. Isolated pollinium. (44-46: Ghillány 209; 47, 49-54: Cordeiro CFSC 6541; 48: Borba 140). 
6. Pseudolaelia citrina Pabst, Bradea 2: 70. 1976. Type: Brazil, Minas Gerais, pr. Ibiraçu, 7/V/1975, Kautsky 490 (Holotype: HB!).

Pseudolaelia maquijiensis M.Frey, Richardiana 5(1): 40. 2005. Type: Brazil, Espírito Santo, limit between the municipalities of Baixo Guandu and Colatina, Morro do Maquiji, 15/V/2004, Frey \& Perim 655 (Holotype: MBML!; Isotype: LY), syn nov.

Pseudolaelia pavopolitana M.Frey, Richardiana 5(4): 204. 2005. Type: Brazil, Espírito Santo, Vila Pavão, Morro do Cruzeiro, 29/V/2004, Frey \& Perim 672 (Holotype: MBML!), syn nov.

Fig. 55-71.

Herb 5-8 cm in height. Rhizome $0.6-2.9 \mathrm{~cm}$ long, green to vinaceous, cataphylls ovate, lanceolate to tubular, ca. $3 \times 5$ $\mathrm{mm}$, apex rounded. Pseudobulb subpyriform to pyriform, $1.2-4.3 \mathrm{~cm}$ long, green to vinaceous, $2-4$ nodes, cataphylls ovate or lanceolate, $0.9-1.7 \times 0.6-0.8 \mathrm{~cm}$, apex acute. Leaves $3-5$, patent to curved, arranged from the middle to the apex of the pseudobulb, linear, $2-13.5 \times 0.2-0.8 \mathrm{~cm}$, dark green to vinaceous, coriaceous, margin entire, apex acute. Panicle ca. 14-44.5 cm long, 6-34 flowers; peduncle ca. 7.5$24.5 \mathrm{~cm}$ long. Flowers odorless, pedicel and ovary 1.1-2.9 cm long; dorsal sepal elliptic to oblanceolate, ca. 0.9-1.1 $\times$ $0.2-0.3 \mathrm{~cm}$, greenish yellow or internally yellow, externally shaded or striped with dark red, apex acute; lateral sepals elliptic to oblanceolate, ca. $9 \times 2-2.5 \mathrm{~mm}$, greenish yellow or internally yellow, externally striate or with vinaceous cast, asymmetrical, concave, apex acute; petals spatulate, $0.9-1 \times$ $0.1-0.15 \mathrm{~cm}$, greenish yellow or internally yellow, externally with vinaceous cast, asymmetrical, apex rounded; labellum 3-lobed, $0.6-1 \times 0.7 \mathrm{~cm}$, lateral lobes triangular-linear to ligulate, 3-4 $\times 0.5-1 \mathrm{~mm}$, yellow, apex acute, median lobe large-ovate or suborbicular, 4-6 $\times 3-4 \mathrm{~mm}$, totally yellow or light yellow with pink cast, apex rounded to acute, disk of the labellum fleshy, with 7-9 lamellae irregular, cream-colored or yellow, verrucose, from the base up to near the apex of the labellum, pilose, trichomes white or yellow; cuniculus externally inconspicuous; column ca. 5-6 mm long, greenish yellow, green or green with vinaceous cast, with apex pink or vinaceous; anther green, pink, brown or vinaceous; pollinia ca. $1 \mathrm{~mm}$, caudicle $0.5-1 \mathrm{~mm}$ long. Ripe fruits brownish green, fusiform, ca. $1.5 \mathrm{~cm}$ long.

Material selected: BRAZIL. Espírito Santo: Colatina, Itapina, Pedra Grande Farm, Morro do Maquiji, 28/VII/2009, fr., Menini Neto \& Fontana 768 (RB). São Roque do Canaã, Alto Misterioso, 1/VIII/2008, fl., Menini Neto \& Fontana 615, (CESJ, RB). Minas Gerais: Mutum, Imbiruçu, Pedra Santa, 31/V/2009, fl., Menini Neto et al. 763 (CESJ, RB). Etymology: reference to the yellow coloration of the flowers. Geographic distribution and habitat: the species occurs in the extreme eastern part of the state of Minas Gerais, as well as in the west, northwest and mountainous region of the state of Espírito Santo (Figure 1). Saxicolous on inselbergs, among lichens and mosses, it forms small populations with isolated cespitose individuals, in elevations that range from 700 to $1200 \mathrm{~m}$ above sea level.

Conservation status: Pseudolaelia citrina might disappear from the type locality (Pedra Santa, Imbiruçu, municipality of Mutum, state of Minas Gerais), given the small number of specimens, as well as human disturbances and the introduction of capim-gordura (a forage grass), which have been destroying the habitat of this species. Another population is located in Sete Salões State Park, in the eastern part of the state of Minas Gerais, although there are no type specimens deposited in any recognized herbarium. This species was classified as vulnerable by Biodiversitas (2005), and as vulnerable and critically endangered, respectively, on the lists of the floras of the states of Minas Gerais (Biodiversitas 2007) and Espírito Santo (Kollmann et al. 2007. It is also cited on the list of endangered flora in Brazil (MMA 2008). A synonymization of $P$. maquijiensis and $P$. pavopolitana with $P$. citrina widens the geographic distribution and the number of populations for this species, but it should be globally categorized as vulnerable (B1ab(iii)B2ab(iii)) (IUCN 2001). It should be noted that only a single population is protected within a conservation unit, Sete Salões State Park. Pseudolaelia citrina is the smallest species of the genus, reaching a height of less than $10 \mathrm{~cm}$, excluding the inflorescence. It also possesses the smallest flowers of the genus, with coloration predominantly yellow, sometimes greenish, and might have sepals with vinaceous cast and, in some populations, labellum with pink cast. Frey (2005), when describing Pseudolaelia maquijiensis, used as distinctive characters the dimensions of vegetative organs (such as the rhizome and pseudobulbs) and reproductive organs (such as the inflorescence, sepals, petals and labellum), stating that $P$. maquijiensis would be larger than P. citrina in various aspects. However, surveys conducted at the type localities of both species clearly indicate that there might have been overlap of these dimensions and the characteristics pointed out by Frey (2005) are part of the natural variation in different populations of a same species. Similarly, the distinction of P. pavopolitana by Frey (2005) was supported by the smaller size and by the coloration of the labellum in comparison with $P$. citrina. The analyses of both types and the similar floral morphology indicate conspecificity. Therefore, $P$. maquijiensis and P. pavopolitana are synonymized with P. citrina.

7. Pseudolaelia corcovadensis Porto \& Brade, Arq. Inst. Biol. Veg. 2: 209. 1935. Type: Brazil, Rio de Janeiro, Corcovado, 20/VI/1935, Voll \& Carris s.n. (Holotype: RB!).

Fig. 72-83.

Herb $15-25 \mathrm{~cm}$ in height. Rhizome $1.9-2.7 \mathrm{~cm}$ long, green, cataphylls ovate, ca. $2 \times 0.7 \mathrm{~cm}$, apex acute. Pseudobulb fusiform, $2.7-5 \mathrm{~cm}$ long, green, 4 internodes, cataphylls lanceolate, ca. $2.5 \times 1 \mathrm{~cm}$, apex acute. Leaves 3-5, erect to slightly curved, arranged from the middle to the apex of the pseudobulb, lanceolate, $7.7-22 \times 0.6-1.1 \mathrm{~cm}$, light 



66
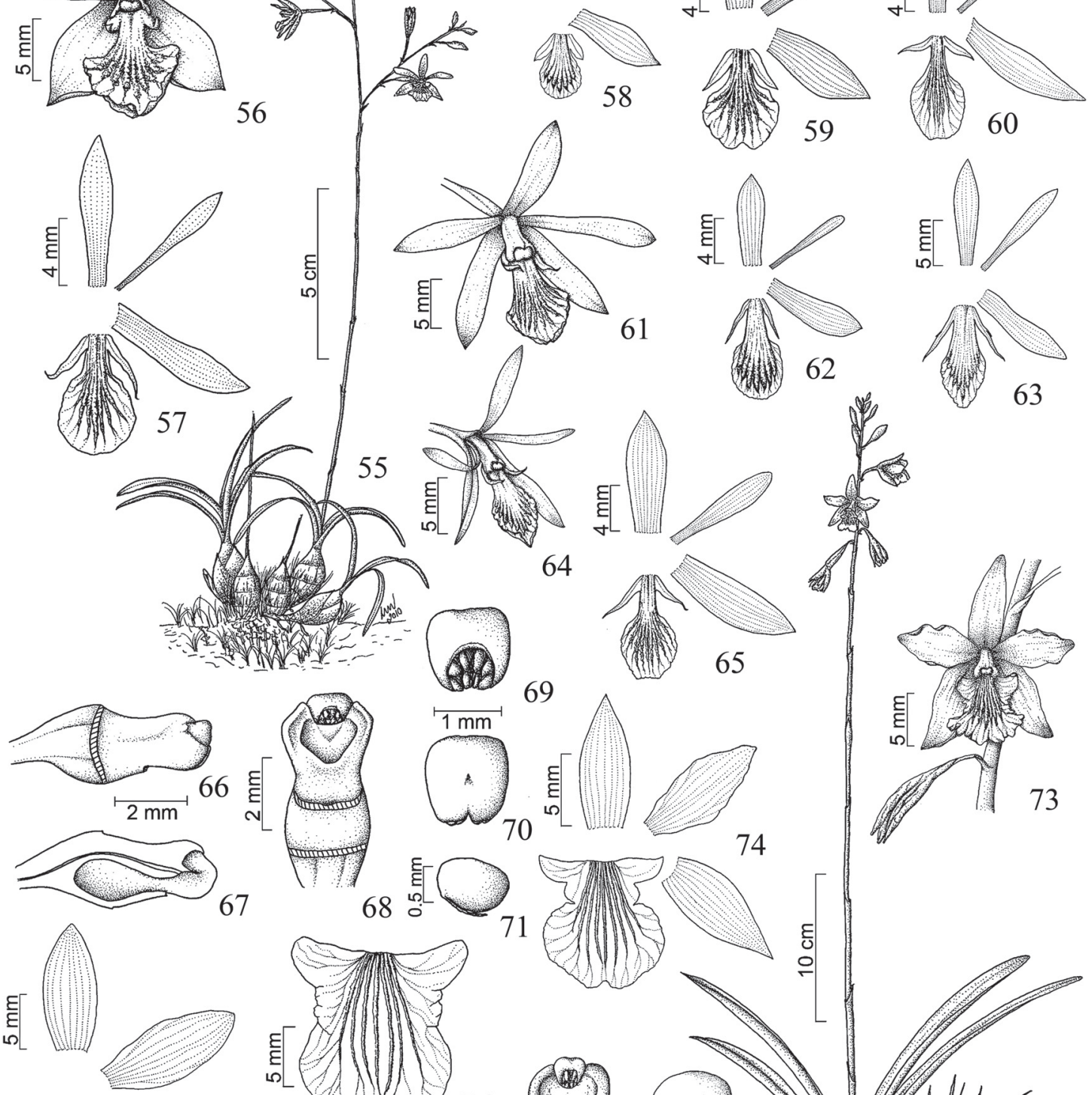

\section{ह[} 68 ํํㅇ
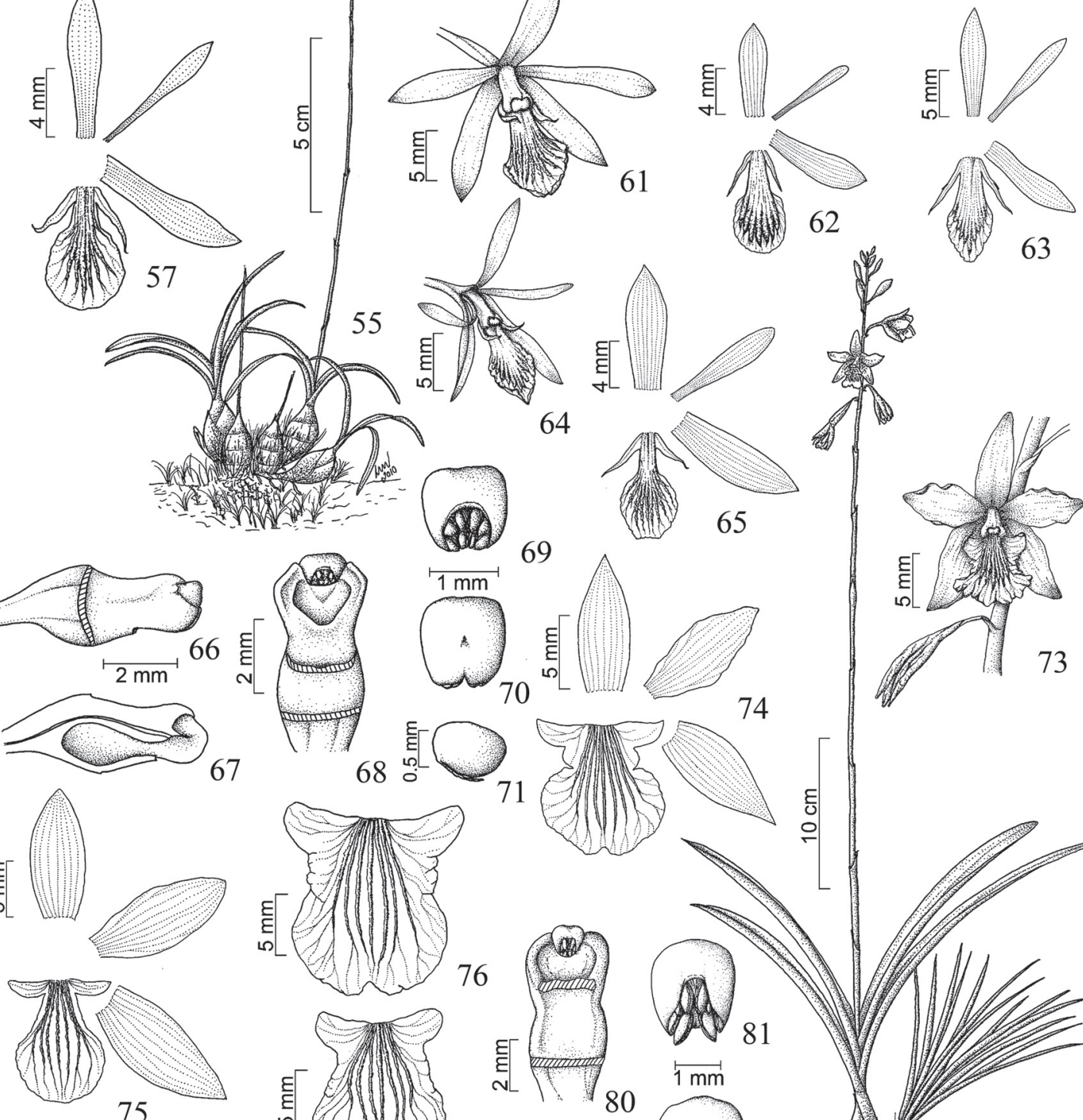

64

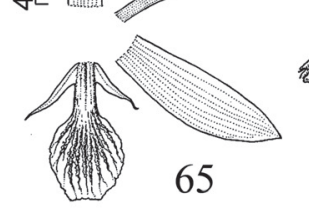

62

74

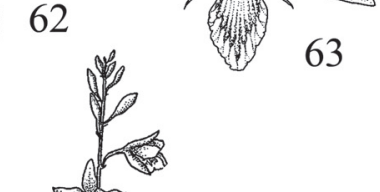

71
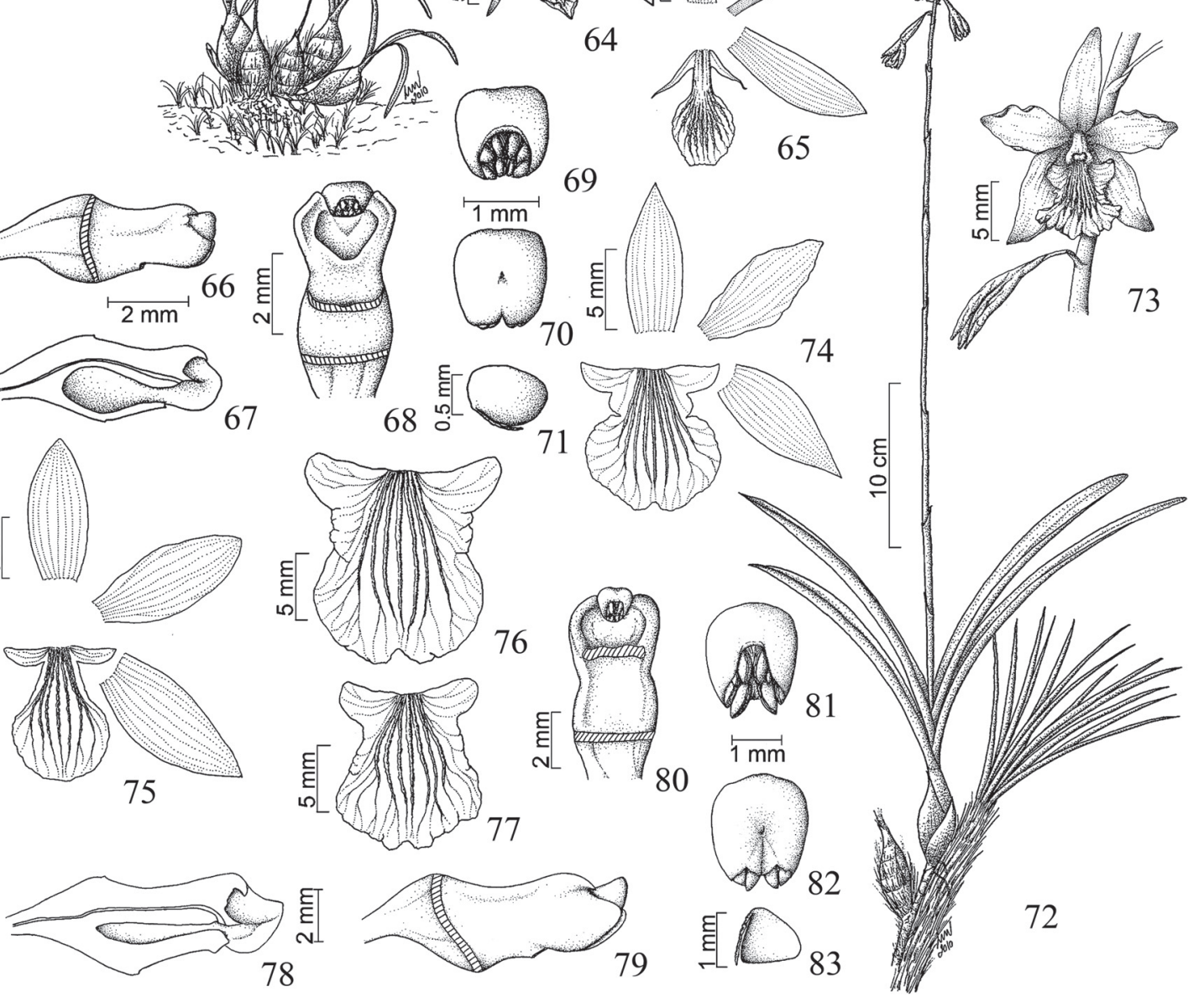

80

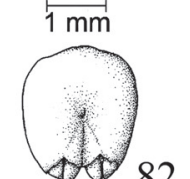

Figures 55-83. Pseudolaelia citrina Pabst: 55. General aspect; 56. General view of the flower; 57-60. Dissected perianth; 61. General view of the flower; 62-63. Dissected perianth; 64. General view of the flower; 65 . Dissected perianth; 66 . Column, lateral view; 67. Column, longitudinal section; 68 . Column, ventral view; 69 , Anther, ventral view; 70. Anther, dorsal view; 71. Isolated pollinium (55-56, 60, 66-71: Menini Neto 763; 57: Kautsky 490; 58: Fontana 883; 59: Bis s.n. (MBML); 61, 65: Menini Neto 615; 62: Fontana 1243; 63-64: Fontana 4831). Pseudolaelia corcovadensis Porto \& Brade: 72. General aspect; 73 . General view of the flower; 74-75. Dissected perianth; 76-77. Details of the labellum; 78. Column, lateral view; 79. Column, longitudinal section; 80 . Column, ventral view; 81 . Anther, ventral view; 82. Anther, dorsal view; 83. Isolated pollinium (72, 76, 78-83: Menini Neto 521; 73-74: Menini Neto 522; 75: Leoni 1813; 77: Menini Neto 401). 
to dark green, coriaceous, apex acute. Raceme or panicle $45-60.5 \mathrm{~cm}$ long, $7-12$ flowers; peduncle $40-52.5 \mathrm{~cm}$ long. Flowers odorless, pedicel and ovary ca. $1.5 \mathrm{~cm}$ long; dorsal sepal elliptic, 1.1-2.2 $\times 0.5-0.8 \mathrm{~cm}$, pink, apex obtuse; lateral sepals elliptic, $1-2 \times 0.5-0.9 \mathrm{~cm}$, pink, asymmetrical, concave, apex acute; petals elliptic, 1.1-2.1 × 0.6-0.9 $\mathrm{cm}$, pink, slightly asymmetrical, apex rounded; labellum 3-lobed, 0.8-1.5 × 0.8-1.5 cm, lateral lobes ligulate, 1.4-4.8 $\times$ 1.7-3.6 mm, pink, apex rounded, median lobe suborbicular, 0.6-1.1 × 0.9-1.4 cm, pink with lines dark pink, apex rounded, disk of the labellum fleshy, with 3-9 lamellae yellow from the base up to near the middle of the median lobe; cuniculus externally inconspicuous; column 7-8 $\mathrm{mm}$ long, pink with apex whitish; anther green; pollinia ca. $1 \mathrm{~mm}$, caudicle ca. $1 \mathrm{~mm}$ long. Ripe fruits light green, globose, ca. $2 \mathrm{~cm}$ long.

Material selected: BRAZIL. Minas Gerais: Juiz de Fora, Santo Cristo Environmentally Protected Area, 3/VI/2008, fl./fr., Menini Neto \& Clemente 521 (CESJ, HUEFS, RB). Rio de Janeiro: Paty do Alferes, Alto da Boa Vista, 7/VI/2008, fl., Menini Neto \& Baltar 522 (CESJ, HUEFS, RB).

Etymology: reference to the Morro do Corcovado, municipality of Rio de Janeiro, supposed type locality of the species. Geographic distribution and habitat: this species occurs in the mountainous region and northern part of the state of Rio de Janeiro and east-southeastern part of the state of Minas Gerais (Figure 1), frequently forming large populations, epiphyte on Vellozia plicata Mart. at elevations ranging from $900 \mathrm{~m}$ to $1400 \mathrm{~m}$ above sea level. Although the label of the type specimen indicates the Corcovado, the species was not collected once more in this locality nor in any other area in the Rio de Janeiro municipality. In the protologue, Porto \& Brade (1935) were surprised with the discovery of a new genus of Orchidaceae in a municipality widely visited by various collectors and naturalists in the XIX and beginning of XX century. We believe the label of the type specimen is mistaken.

Conservation status: classified as endangered for in state of Minas Gerais (Biodiversitas 2007). Of the four records for that state, one of the populations in the municipality of Juiz de Fora has already been practically destroyed because it is located in an active quarry. The species should be globally categorized as endangered (B1ab(iii) B2a), according to the IUCN criteria (IUCN 2001).

Pseudolaelia corcovadensis is most similar to P. cipoensis, P. geraensis and P. irwiniana, due to the wide sepals and petals, and can be differentiated by the larger flowers, the presence of 5-9 well-developed yellow lamellae in the disk of the labellum, and the markedly undulate margin of the labellum. It has a distinctive geographic distribution, on granitic inselbergs in the southeastern part of the state of Minas Gerais and in the state of Rio de Janeiro, whereas the other species occur in the central and northeastern parts of Minas Gerais, P. cipoensis and P. irwiniana occurring exclusively in rocky grasslands.
8. Pseudolaelia dutrae Ruschi, Bol. Mus. Biol. Prof. Mello-Leitão. Sér. Bot. 1: 40. 1949. Lectotype designated by Menini Neto et al. (2011): Brazil, Espírito Santo, Santa Teresa, Barra do Rio Perdido, 3/VII/1948, Ruschi 1502 (MBML!).

Pseudolaelia freyi Chiron \& V.P.Castro, Richardiana 4(4): 157. 2004. Type: Brazil, Espírito Santo, municipality of Brejetuba, Monte Feio, 28/VI/2004, Frey \& Perim 702 (Holotype: MBML!), syn nov.

Fig. 84-98.

Herb $20-30 \mathrm{~cm}$ in height. Rhizome $0.5-8 \mathrm{~cm}$ long, green to brownish vinaceous, cataphylls ovate, ca. $1.5 \times 1 \mathrm{~cm}$, apex acute. Pseudobulb fusiform to subpyriform, 3-10.5 cm long, green to brownish, 4-5 internodes, cataphylls ovate to lanceolate, 1.6-4 $\times 1-1.5 \mathrm{~cm}$, apex acute. Leaves $3-7$, erect to slightly curved, arranged from the middle to the apex of the pseudobulb, lanceolate, 7.4-33.4 $\times 0.7-2.2 \mathrm{~cm}$, dark green to vinaceous cast, coriaceous, serrulate margin, apex acute. Raceme or panicle with short branches, $34.5-80 \mathrm{~cm}$ long, 20-110 flowers; peduncle $19-60.5 \mathrm{~cm}$ long. Flowers odorless, pedicel and ovary $1.1-2.6 \mathrm{~cm}$ long; dorsal sepal oblanceolate, $1.1-2.8 \times 0.2-0.5 \mathrm{~cm}$, white to dark pink, slightly asymmetrical, slightly concave, apex acute; lateral sepals oblanceolate, $1.1-2.7 \times 0.3-0.6 \mathrm{~cm}$, white to dark pink, asymmetrical, concave, apex acute; petals spatulate to oblanceolate, $1.2-2.9 \times 0.2-0.6 \mathrm{~cm}$, white to dark pink, slightly asymmetrical to asymmetrical, apex acute to rounded; labellum 3-lobed, $10-1.7 \times 1.1-1.3 \mathrm{~cm}$, lateral lobes linear to oblong, $1.5-9.2 \times 0.5-2 \mathrm{~mm}$, white to dark pink, apex acute to rounded, median lobe reniform to suborbicular, $0.3-0.9 \times 0.5-1.1 \mathrm{~cm}$, white to dark pink, striped with pink to dark pink, margin erose or fimbriate, apex deeply emarginate, rarely obtuse, disk of the labellum fleshy, pilose, with two lamellae from the base, forming several longitudinal lamellae with apex verrucose, which stand out near the base of the median lobe, white to yellow; cuniculus externally inconspicuous; column ca. 6-7 $\mathrm{mm}$ long, white, green to pink green, sometimes with apex purplish; anther purple; pollinia ca. $1 \mathrm{~mm}$, caudicle ca. $1 \mathrm{~mm}$ long. Ripe fruits globose, $1.4-2 \mathrm{~cm}$ long, green.

Material selected: BRAZIL. Espírito Santo: Brejetuba, Monte Feio, 27/VII/2009, fl./fr., Menini Neto \& Fontana 766 (CESJ, HUEFS, RB); Vila Pavão, Comunidade Figueira, 29/V/2009, fl., Menini Neto et al. 756 (CESJ, HUEFS, RB). Minas Gerais: Aimorés, inselberg contiguous to the Pedra Lorena, near the Usina de Aimorés, fl., Menini Neto et al. 762 (CESJ, RB).

Etymology: homage to Eurico Gaspar Dutra, president of Brazil at the time the species was described.

Geographic distribution and habitat: the species forms large populations in granitic outcrops predominantly in the state of Espírito Santo, as well as the state of Minas Gerais (Figure 2), at a wide range of elevations, from $140 \mathrm{~m}$ to $1300 \mathrm{~m}$ above sea level. Epiphyte on Velloziaceae, rarely saxicolous. Conservation status: because of its wide distribution and great number of known populations, usually with numerous individuals, this species should be categorized as least concern (IUCN 2001). 
Pseudolaelia dutrae displays strong floral polymorphism and greater similarity with $P$. vellozicola. It can be differentiated from the latter by the usually larger size, inflorescence frequently in panicle with secondary branches shorter and fairly compact ( $v s$. frequently in raceme), flowers with sepals and petals usually narrower and median lobe of the labellum with margin markedly erose or fimbriate, apex deeply emarginate, longitudinal lamellae with verrucose apex, which stand out near the base of the median lobe (vs. labellum with margin entire, apex frequently rounded and longitudinal lamellae that stand out throughout all its extension). Chiron \& Castro Neto (2004) described $P$. freyi based in material originated from Monte Feio, in the municipality of Brejetuba (state of Espírito Santo), and differentiated it from $P$. dutrae by the smaller size, shorter inflorescence, in raceme (or with few branches), shorter rhizome, callosity divided in crest at half of the length ( $v s$. at the apex), labellum with yellow isthmus (vs. white) and lateral lobes of the labellum shorter than wide. A population analysis in Brejetuba at the peak of flowering demonstrated that these characteristics are variable. The number of branches of the inflorescence also varies within the population in Brejetuba and in other populations. The other populations of $P$. dutrae also display strong floral intrapopulation and interpopulation polymorphism, as shown by Menini Neto (2011) in a study of the flower morphometry. Similarly, the study of genetic diversity did not indicate that $P$. dutrae and P. freyi are distinct species (Menini Neto 2011). Therefore, we here synonymize $P$. freyi with $P$. dutrae.

9. Pseudolaelia geraensis Pabst, Orquídea (Rio de Janeiro) 29: 63. 1967. Lectotype designated by Menini Neto et al. (2011): Brazil, Minas Gerais, road Nanuque-Teófilo Ottoni, 14/VIII/1965, Belém 1629 (Holotype: CEPEC, lost; Lectotype: HB!; Isolectotype: NY foto!, UB foto!).

Fig. 99-115.

Herb $25-35 \mathrm{~cm}$ in height. Rhizome $3.3-18.5 \mathrm{~cm}$ long, green to yellowish green, cataphylls tubular, $0.9-1.9 \times$ ca. $0.9 \mathrm{~cm}$, apex acute. Pseudobulb fusiform, $4.9-9.3 \mathrm{~cm}$ long, light to yellowish green, 4 internodes, cataphylls lanceolate, ca. 4 $\times 1.5 \mathrm{~cm}$, apex acute. Leaves $4-7$, erect, arranged from the middle to the apex of the pseudobulb, elliptic to lanceolate, 9.8-23.6 $\times 0.87-3.4 \mathrm{~cm}$, green to yellowish green, coriaceous, margin serrulate, apex acute to asymmetrical. Raceme 61-166 cm long, 10-25 flowers; peduncle $60-149 \mathrm{~cm}$ long. Flowers odorless, pedicel and ovary $1.5-2.6 \mathrm{~cm}$ long, pink; dorsal sepal oblanceolate, $1.4-2 \times 0.5-0.7 \mathrm{~cm}$, white to pink, slightly asymmetrical, apex acute; lateral sepals oblanceolate, $1.4-2 \times 0.6-0.8 \mathrm{~cm}$, white to pink, asymmetrical, concave, apex acute; petals spatulate, $1.2-2 \times 0.5-0.8 \mathrm{~cm}$, white to pink, asymmetrical, apex acute; labellum 3-lobed, 0.9-1.4 $\times 0.8-1.3 \mathrm{~cm}$, lateral lobes triangular, $0.5-4 \times 0.4-2.3 \mathrm{~mm}$, white to pink, apex acute, median lobe reniform, ca. $0.5 \times$ $1 \mathrm{~cm}$, white to pink with dark pink lines, apex emarginate, disk of the labellum fleshy, with 2 parallel basal calli diverg- ing into several poorly developed lamellae up to near the median lobe; cuniculus externally inconspicuous; column 5-6 mm long, pink with green cast; anther green; pollinia ca. $1 \mathrm{~mm}$, caudicle ca. $1 \mathrm{~mm}$ long. Ripe fruits globose, ca. $1.8 \mathrm{~cm}$ long, green.

Material selected: BRAZIL. Bahia: No municipality, Next to the road BR-4, km 777, 27/VI/1968, fl., Belém 3776 (CEPEC). Minas Gerais: Nova Era, property of CENIBRA, 17/V/2008, fl., Menini Neto \& Drummond 519 (CESJ, HUEFS, RB). Espírito Santo: No municipality, fl. cult. 26/ XI/ 1978, fl., Burle-Marx s.n. (HB 69137).

Etymology: reference to the state of Minas Gerais, where the species was first observed.

Geographic distribution and habitat: distributed from the south of the state of Bahia up to the border with the state of Espírito Santo, extending to the northeastern and central parts of the state of Minas Gerais State (Figure 2). Saxicolous, on the granitic inselbergs in the state of Bahia and northeastern part of the state of Minas Gerais, or epiphyte on Vellozia plicata, on outcrops in the central-east region of the state of Minas Gerais and mountainous region of the state of Espírito Santo at elevations ranging from $300 \mathrm{~m}$ to $1400 \mathrm{~m}$ above sea level.

Conservation status: although this species is widely distributed, according to the IUCN (2001) criteria, it should be categorized as vulnerable (B1ab(iii)B2a), mainly because of the fragmented distribution and the fact that there are records for only a small number of localities.

Pseudolaelia geraensis is most similar to $P$. corcovadensis, $P$. cipoensis and $P$. irwiniana, sharing flowers with large sepals and petals, being differentiated from those species by the larger pseudobulbs, larger leaves in larger numbers, inflorescence frequently exceeding one meter in length, labellum with two basal calli, with projections forming a central longitudinal groove, which extends over the median lobe as poorly developed divergent lamellae. This last characteristic is also present in P. cipoensis, but the flowers are smaller and the lateral lobes are more developed and narrower than in P. geraensis. The plants of the northeastern part of the state of Minas Gerais, in the region of the type locality, are more robust and display longer inflorescences (exceeding $1 \mathrm{~m}$ in length) and smaller flowers, forming large clumps in association with Bromeliaceae, Cactaceae, lichens and mosses, whereas the plants that occur more to the south of the state and in the state of Espírito Santo are less robust, usually with shorter inflorescences and flowers that are less developed.

10. Pseudolaelia irwiniana Pabst, Bradea 1: 366. 1973. Type: Brazil, Minas Gerais, $18 \mathrm{~km}$ E of Diamantina, 16/ III/1970, Irwin et al. 27706 (Holotype: UB Foto!; Isotype: HB!, NY foto!).

Fig. 116-127.

Herb ca. $15 \mathrm{~cm}$ in height. Rhizome $1.5-2 \mathrm{~cm}$ long, vinaceous, cataphylls ovate, ca. $6 \times 4 \mathrm{~mm}$, apex acute. Pseudobulb fusiform, ca. 3-4 cm long, vinaceous, 4 internodes, cataphylls 
lanceolate, ca. $8 \times 5 \mathrm{~mm}$, apex acute. Leaves $2-3$, erect, arranged from the middle to the apex of the pseudobulb, linear-lanceolate, $10-13 \times \mathrm{ca} .1 \mathrm{~cm}$, dark green to vinaceous, coriaceous, margin serrulate, apex acute. Raceme ca. 20-30 $\mathrm{cm}$ long, 8-13 flowers; peduncle 18-27.5 cm long. Flowers odorless, pedicel and ovary ca. $1 \mathrm{~cm}$ long; dorsal sepal elliptic, 1.1-1.6 $\times 0.3-0.5 \mathrm{~cm}$, pink, apex acute; lateral sepals lanceolate, $1-1.6 \times 0.3-0.5 \mathrm{~cm}$, pink, asymmetrical, concave, apex acute; petals spatulate, $1-1.6 \times 0.3-0.6 \mathrm{~cm}$, pink, asymmetrical, apex acute; labellum 3-lobed, 0.7-1 × 0.8-1 cm, lateral lobes triangular to ligulate, $1-3 \times 0.8-1.5 \mathrm{~mm}$, pink, apex rounded, median lobe suborbicular to reniform, 0.6$0.8 \times 0.8-1 \mathrm{~cm}$, pink with dark pink lines, apex rounded to emarginate, apiculate, disk of the labellum fleshy, with 5-7 lamellae longitudinal yellow changing to dark pink, from the base up to near the apex of the median lobe; cuniculus externally inconspicuous; column 3-4 mm long, green pink with apex whitish; anther green; pollinia ca. $1 \mathrm{~mm}$, caudicle ca. $0.5 \mathrm{~mm}$ long. Fruits spherical, $1.5-1.8 \mathrm{~cm}$ long, green. Material selected: BRAZIL. Minas Gerais: Diamantina, Curralinho, fl. cult. em X.2006, fl., Menini Neto et al. 622 (CESJ). Etymology: homage to the botanist Howard Samuel Irwin, who collected the type specimen.

Geographic distribution and habitat: occurs only in the rocky grasslands of the Planalto de Diamantina, state of Minas Gerais (Figure 2), at elevations ranging from $1000 \mathrm{~m}$ to $1300 \mathrm{~m}$ above sea level. Frequently epiphytic on species similar to Vellozia hirsuta Goeth. \& Henrard, this species is hard to distinguish from its phorophytes because of the similar foliar morphology, with markedly creeping growth. Conservation status: this species should be categorized as endangered (B1ab(iii)B2ab(iii)) according to the IUCN criteria (IUCN 2001), mainly because of the environmental degradation of the area, which is largely exploited for diamond mining, as well as because there is only one known population, located in a conservation unit.

Pseudolaelia irwiniana is most similar to P. cipoensis, but can be differentiated for being the smallest of the species of Pseudolaelia with epiphytic life form, with pseudobulbs no more than $4 \mathrm{~cm}$ long, vinaceous, with 2-3 leaves $(v s .4$ leaves in P. cipoensis), erect and narrower and inflorescence with flowers grouped near the apex ( $v s$. flowers with more regularly arranged in P. cipoensis). A population recorded in Capivari (district of the municipality of Serro) displays floral morphology intermediate between $P$. irwiniana and P. vellozicola, although it is possible to identify the latter by its vegetative characteristics. However, there is a possibility for hybridization, because these species are sympatric in the Planalto de Diamantina.

11. Pseudolaelia pitengoensis Campacci, Boletim $\mathrm{CAOB}$ 71: 60. 2008. Type: Brasil, Minas Gerais, Nova Belém, Serra do Pitengo, VII/2007 (fl. cult. V.2000), Campacci 1918 (Holotype: UNIP!).

Fig. 128-136.
Herb $15-20 \mathrm{~cm}$ in height. Rhizome 1-1.7 cm long, green to vinaceous, cataphylls ovate, ca. $4 \times 4 \mathrm{~mm}$, apex acute. Pseudobulb fusiform to subpyriform, $2.9-5.6 \mathrm{~cm}$ long, light green to vinaceous, 4 internodes, cataphylls lanceolate, 1.6-2.4 $\times$ ca. $0.8 \mathrm{~cm}$, apex acute. Leaves $4-6$, erect, arranged from the middle to the apex of the pseudobulb, lanceolate, 6.8-18 $\times$ 0.7-1.4 cm, dark green, coriaceous, margin serrulate, apex acute. Panicle $39-73.5 \mathrm{~cm}$ long, branches of the inflorescence $2.5-5 \mathrm{~cm}$ long, $10-50$ flowers; peduncle $34-50 \mathrm{~cm}$ long. Flowers odorless, pedicel and ovary 1.2-1.8 cm long; dorsal sepal oblanceolate, ca. $1 \times 0.25 \mathrm{~cm}$, greenish yellow, apex acute; lateral sepals oblanceolate, ca. $9 \times 3 \mathrm{~mm}$, greenish yellow, asymmetrical, concave, apex acute; petals spatulate, ca. $1 \times 0.2 \mathrm{~cm}$, yellow, asymmetrical, apex acute; labellum 3-lobed, ca. $9 \times 6.5 \mathrm{~mm}$, lateral lobes triangular, ca. $2 \times 1$ $\mathrm{mm}$, greenish yellow, apex acute, median lobe reniform, ca. $5 \times 6.5 \mathrm{~mm}$, vinaceous, surface papillose, apex emarginate, disk of the labellum yellow, fleshy, without lamellae; cuniculus externally inconspicuous; column ca. 4-5 mm long, yellowish green with apex purplish; anther purple; pollinia ca. $1 \mathrm{~mm}$, caudicle ca. $0.3 \mathrm{~mm}$ long. Fruits subspherical, ca. $1.2 \mathrm{~cm}$ long, dark green.

Material examined: BRAZIL. Minas Gerais: Nova Belém, Serra do Pitengo, 30/V/2009, fl./fr., Menini Neto et al. 760 (CESJ, HUEFS, RB).

Etymology: reference to the Serra do Pitengo, state of Minas Gerais, type locality of the species.

Geographic distribution and habitat: the species is known only at the type locality, in the Serra do Pitengo, municipality of Nova Belém, state of Minas Gerais (Figure 2). Epiphyte on Vellozia plicata, the species forms a large population at approximately $600 \mathrm{~m}$ above sea level.

Conservation status: the species should be categorized as vulnerable (D2) according to the IUCN criteria (IUCN 2001), because it has only a single known population in a small area of occupancy, unprotected, and susceptible to the effects of human activity and stochastic events, such as fire.

Pseudolaelia pitengoensis possesses floral characteristics similar to those of $P$. ataleiensis and P. canaanensis, all sympatric species. It can be differentiated from these species by the smaller size and smaller number of leaves, presence of lateral lobes in the labellum, although reduced ( $v s$. lateral lobes absent in both species and labellum 2-lobed or entire, respectively, in $P$. ataleiensis and $P$. canaanensis), smaller inflorescence, with less flowers, distinguished from $P$. canaanensis by the absence of foliate projection at the apex of the pseudobulb. It should be noted that $P$. pitengoensis is exclusively epiphytic on Vellozia, whereas the other two species are saxicolous.

12. Pseudolaelia vellozicola (Hoehne) Porto \& Brade, Arq. Inst. Biol. Veg. 2: 211. 1935. 三 Schomburgkia vellozicola Hoehne, Bol. Agric. (São Paulo) 34: 622. 1934. Lectotype designated by Menini Neto et al. (2011): plate number 11 of the original publication of Schomburgkia vellozicola. 




Figures 84-127. Pseudolaelia dutrae Ruschi: 84. General aspect; 85. General view of the flower; 86. Dissected perianth; 87-92. Details of the labellum; 93. Column, lateral view; 94. Column, longitudinal section; 95. Column, ventral view; 96, Anther, ventral view; 97. Anther, dorsal view; 98. Isolated pollinium (84-86, 93-98: Menini Neto 613; 87: Fontana 3388; 88: Tameirão Neto 2373; 89: Duarte 13977; 90: Fontana 2341; 91: Lagasa 211; 92: Fontana 123). Pseudolaelia geraensis Pabst: 99. General aspect; 100. General view of the flower; 101. Dissected perianth; 102-109. Details of the labellum; 110. Column, lateral view; 111. Column, longitudinal section; 112. Column, ventral view; 113, Anther, ventral view; 114. Anther, dorsal view; 115. Isolated pollinium (99, 101, 110-115: Menini Neto 753; 100, 106-108: Menini Neto 764; 102-105: Menini Neto 519). Pseudolaelia irwiniana Pabst: 116. General aspect; 117. General view of the flower; 118-119. Dissected perianth; 120121. Details of the labellum; 122. Column, lateral view; 123. Column, longitudinal section; 124. Column, ventral view; 125, Anther, dorsal view; 126 . Anther, ventral view; 127. Isolated pollinium. (116-117, 120-127: Menini Neto 622; 118: Santos 652; 119: Forzza 617). 
Pseudolaelia regentii V.P.Castro \& Marçal, Richardiana 8(1): 7. 2007. Type: Brazil, Bahia, Rio de Contas, Paramirim, s.d., Marçal s.n. (Holotype: SP. Not deposited). Lectotype: Figure 2 of original work, here designated. Syn nov.

Pseudolaelia oliveirana V.P.Castro \& Chiron, Richardiana 9(1): 22. 2009. Type: Brazil, Espírito Santo, Pancas, s.d., Pinto s.n. (Holotype: SP. Not deposited). Lectotype: Figure 1 of original work, here designated. Syn nov.

Pseudolaelia calimaniorum V.P.Castro \& Chiron, Richardiana 9(1): 25. 2009. Type: Brazil, Espírito Santo, Venda Nova do Imigrante, s.d., Caliman s.n. (Holotype: SP. Not deposited). Lectotype: Figure 4 of original work, here designated. Syn nov.

Fig. 137-154.

Herb $15-25 \mathrm{~cm}$ in height. Rhizome ca. 2-7.7 cm long, yellowish green to vinaceous, cataphylls ovate, ca. $1.9 \times$ $1 \mathrm{~cm}$, apex acute. Pseudobulb fusiform, $2.3-7.8 \mathrm{~cm}$ long, yellowish green to vinaceous, 4-5 internodes, cataphylls lanceolate, 2-3.8 $\times 1-1.5 \mathrm{~cm}$, apex acute. Leaves $4-6$, erect to slightly curved, arranged from the middle to the apex of the pseudobulb, lanceolate to linear-lanceolate, 6.4-27 × 0.4-1.1 $\mathrm{cm}$, dark green, coriaceous, margin serrulate, apex acute. Raceme or, less frequently, panicle, $24 .-75.5 \mathrm{~cm}$ long, 10-30 flowers; peduncle ca. 21.5-69 cm long. Flowers odorless, pedicel and ovary $0.8-2.2 \mathrm{~cm}$ long; dorsal sepal elliptic to oblanceolate, $1-2.5 \times 0.2-0.6 \mathrm{~cm}$, white, pink to dark pink, symmetrical to slightly asymmetrical, apex acute; lateral sepals narrow-elliptic to oblanceolate, $1-2.5 \times 0.2-0.7 \mathrm{~cm}$, white, pink to dark pink, asymmetrical, slightly concave, apex acute to acuminate; petals elliptic, falciform, oblanceolate or spatulate, $1.1-2.7 \times 0.2-0.4 \mathrm{~cm}$, white, pink to dark pink, symmetrical to asymmetrical, apex acute to rounded; labellum 3-lobed, 0.9-1.8 $\times 0.4-1.4 \mathrm{~cm}$, lateral lobes triangular, falciform, lanceolate, elliptic, ligulate or linear, 2-6.5 $\times 0.5-2 \mathrm{~mm}$, white to pink, apex acute, long-acuminate or rounded, median lobe suborbicular or large-ovate, 7-8 $\times$ 6-9 mm, pink with lines dark pink, margin entire, apex rounded, sometimes emarginate or apiculate, disk of the labellum fleshy, with 3-7 lamellae longitudinal, yellow from the base up to near the middle of the median lobe; cuniculus externally inconspicuous; column 5-6 mm long, green with pink cast to pink; anther green to pink; pollinia ca. $1 \mathrm{~mm}$, caudicle ca. $1 \mathrm{~mm}$ long. Fruits subspherical, ca 1. cm long, green.

Material examined: BRAZIL. Bahia: Maracás, $8 \mathrm{~km}$ along the road to Contendas do Sincorá, Pedra Ladeira, 1/ XII/2009, fl./fr., Menini Neto \& van den Berg 769 (CESJ, $\mathrm{RB})$. Espírito Santo: Água Doce do Norte, Pedra da Antena, 29/V/2009, fl., Menini Neto et al. 757 (CESJ, HUEFS, RB). Minas Gerais: Ataléia, near Roncamento, 28/V/2009, fl., Menini Neto et al. 754, (CESJ, HUEFS, RB). Rio de Janeiro: Campos dos Goytacazes, Morro do Itaoca, 27/V/2008, fl./ fr., Menini Neto et al. 520 (CESJ, HUEFS, RB).

Etymology: allusion to the epiphytism on species of Velloziaceae.
Geographic distribution and habitat: this is the species with the widest geographic distribution within the genus, occurring from sea level to approximately $1500 \mathrm{~m}$ above sea level. It occurs from the southeastern and southwestern parts of the state of Bahia to the states of Minas Gerais and Espírito Santo, also occurring in the northern part of the state of Rio de Janeiro (Figure 3). The species can also be found in the rocky grasslands of Bahia and Minas Gerais, on the inselbergs in the east-southeastern part of Minas Gerais and northern part of the state of Rio de Janeiro. In addition, it occurs in the restingas (coastal woodlands) of Espírito Santo, although it is more common on inselbergs in that state, among the coastal outcrops and in the mountainous region. Epiphyte on Velloziaceae, or more rarely saxicolous, this species frequently forms large populations.

Conservation status: because of the wide geographic distribution, area of occupancy and populations usually comprised of a large number of individuals, the species should be categorized as least concern, according to the criteria of IUCN (2001).

Pseudolaelia vellozicola has an extremely variable floral morphology, and is the Pseudolaelia species with the widest geographic distribution and the greatest degree of genetic polymorphism (Menini Neto 2011). Pseudolaelia vellozicola is similar to $P$. dutrae but can be differentiated by the inflorescence in raceme ( $v s$. frequently in panicle in $P$. dutrae), labellum with margin entire and apex of the median lobe usually rounded ( $v s$. margin fimbriate or markedly erose and apex deeply emarginate) and longitudinal lamellae from the base up to near the apex of the median lobe ( $v s$. lamellae that stand out near the base of the median lobe, verrucose). The descriptions of P. regentii (Castro Neto \& Marçal 2007) for the state of Bahia, as well as those of $P$. calimaniorum and P. oliveirana (Castro Neto \& Chiron 2008) for the state of Espírito Santo, are mainly based on floral characteristics that are widely variable, even from an intrapopulational perspective, such as length and width of the sepals and petals, length and form of the isthmus and apex of the labellum. There were no type specimens deposited in the SP herbarium for any of the three binomials, as reported in the protologue. Those binomials are here typified, and the illustrations of the original works of each were chosen as lectotypes. The analyses of linear and geometric morphometry of the flowers and of the genetic diversity (Menini Neto 2011) support the acceptance of the species P. vellozicola with wide distribution and pronounced polymorphism. The variation observed can be explained by the fact that the populations occur on inselbergs that act like relatively isolated islands in the Atlantic forest and on outcrops in rocky grasslands, without an accentuated genetic exchange and with the possibility of morphologic differentiation through isolation. Hence, we here synonymize $P$. regentii, $P$. calimaniorum and $P$. oliveirana with $P$. vellozicola. 


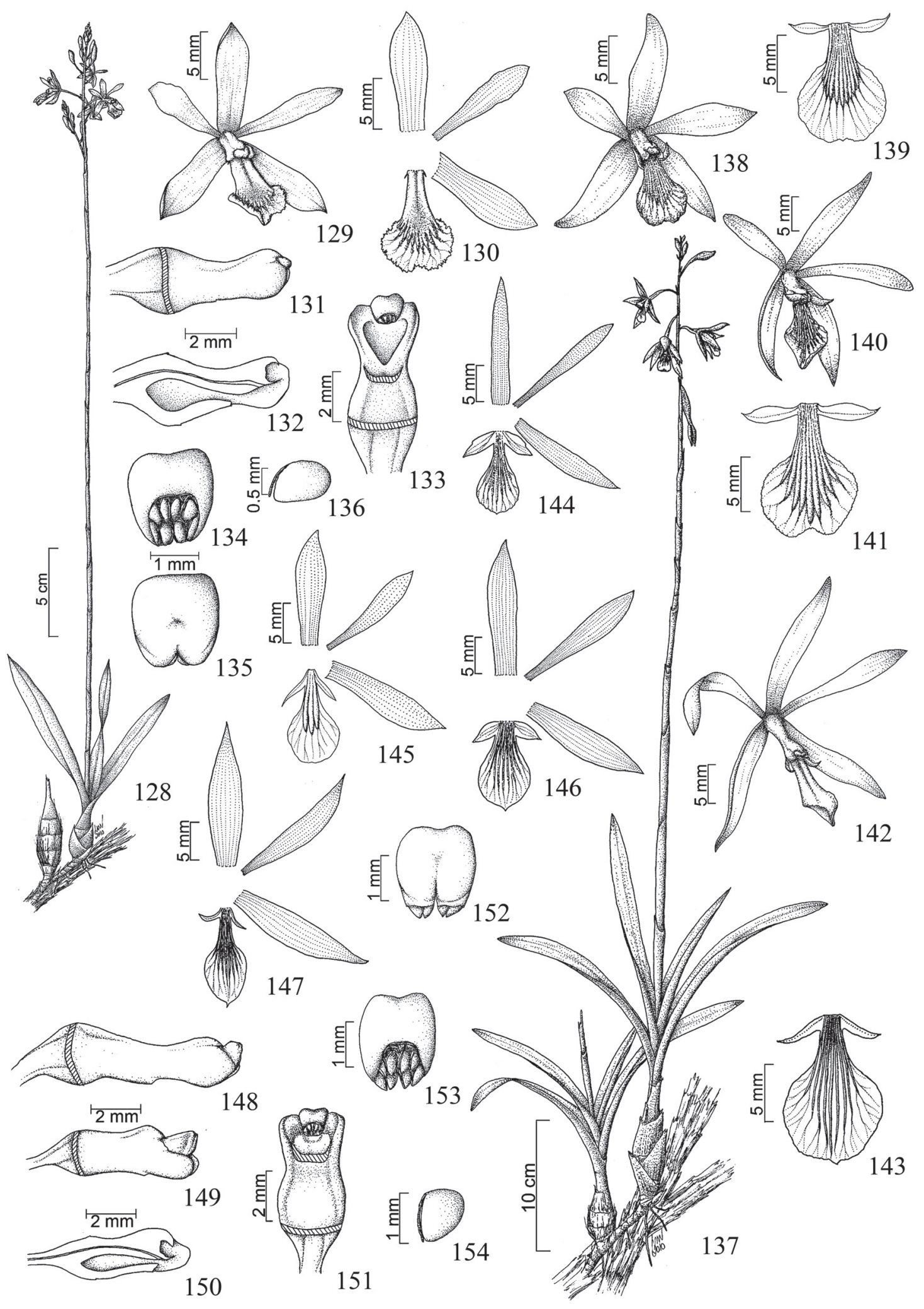

Figures 128-154. Pseudolaelia pitengoensis Campacci: 128. General aspect; 129. General view of the flower; 130. Dissected perianth; 131. Column, lateral view; 132. Column, longitudinal section; 133. Column, ventral view; 134. Anther, ventral view; 135. Anther, dorsal view; 136. Isolated pollinium (128-136: Menini Neto 760). Pseudolaelia vellozicola (Hoehne) Porto \& Brade: 137. General aspect; 138. General view of the flower; 139 . Details of the labellum; 140 . General view of the flower; 141. Details of the labellum; 142. General view of the flower; 143. Details of the labellum; 144-147. Dissected perianth; 148-149. Column, lateral view; 150. Column, longitudinal section; 151. Column, ventral view; 152, Anther, dorsal view; 153. Anther, ventral view; 154. Isolated pollinium (137-139, 148-154: Menini Neto 520; 140-141: Kollmann 11746; 142-143: no collector (MBML 31321); 144: Pinheiro 165; 145: Forzza 794; 146: Hoffmann s.n. (HB 63499); 147: Pinheiro 35). 


\section{Acknowledgments}

We thank the herbarium curators for the receipt and loan of the specimens cited in this study. We are also grateful to Drs. Fábio de Barros, Christiano Verola, Andrea Costa, Dorothy Araújo and Ruy J. Válka Alves for their critical evaluation and suggestions. This study received financial support from the Brazilian Conselho Nacional de Desenvolvimento Científico e Tecnológico (CNPq, National Council for Scientific and Technological Development; "sandwich"1 doctoral scolarship to L.M.N. and productivity scolarship to R.C.F. and C.B.)

\section{References}

Alves, R.J.V. 1992. A new species of Pseudolaelia (Orchidaceae) from Minas Gerais, Brazil. Folia Geobotanica et Phytotaxonomica 27: 189-191.

Barros, F. 1994. Novas combinações, novas ocorrências e notas sobre as espécies pouco conhecidas para as orquídeas do Brasil. Acta Botanica Brasilica 8(1): 11-17.

Barros, F. 2002. Notas taxonômicas para espécies brasileiras dos gêneros Epidendrum e Heterotaxis (Orchidaceae). Hoehnea 29(2): 109-113.

Barros, F.; Vinhos, F.; Rodrigues, V.T.; Barberena, F.F.V.A. \& Fraga, C.N. 2010. Orchidaceae. Pp. 1344-1426. In: Forzza, R.C.; Baumgratz, J.F.A.; Bicudo, C.E.M.; Carvalho Jr. A.A.; Costa, A.; Costa, D.P.; Hopkins, M.; Leitman, P.M.; Lohmann, L.G.; Maia, L.C.; Martinelli, G.; Menezes, M.; Morim, M.P.; Coelho, M.A.N.; Peixoto, A.L.; Piran,i J.R.; Prado, J.; Queiroz, L.P.; Souza, V.C.; Stehmann, J.R.; Sylvestre, L.S.; Walter, B.M.T. \& Zappi, D. (Eds.). Catálogo de plantas e fungos do Brasil, v. II. Rio de Janeiro, Jardim Botânico do Rio de Janeiro.

Biodiversitas. 2005. Revisão da lista da flora brasileira ameaçada de extinção. Disponível em: http://www.biodiversitas.org.br/floraBr/. (Acesso em 20/07/2010).

Biodiversitas. 2007. Revisão das listas das espécies da flora e da fauna ameaçadas de extinção do estado de Minas Gerais. v. 2. Fundação Biodiversitas, Belo Horizonte.

Campacci, M.A. 2008. Duas novas orquídeas de Minas Gerais. Boletim CAOB 71: 56-64.

Campacci, M.A. 2009. Coletânea de Orquídeas Brasileiras 7. Editora Brasil Orquídeas, Taubaté.

Castro Neto, V.P. \& Marçal, S. 2007. Une nouvelle espèce de Pseudolaelia de Bahia (Brésil). Richardiana 8(1): 6-11.

Castro Neto, V.P. \& Chiron, G.R. 2009. Contribution à la connaissance dês orchidées du Brésil. XV: deux nouvelles espèces de Pseudolaelia de létat d'Espírito Santo (Brésil). Richardiana 9(1): 20-28.

Chiron, G.R. \& Castro Neto, V.P. 2004. Contribution à la connaisance dês orchidées du Brésil. Richardiana 4(4): 156-162.

Frey, M. 2003. Pseudolaelia brejetubensis M.Frey (Orchidaceae), uma nova espécie do Espírito Santo, Brasil. Bradea 9(8): 33-36.

Frey, M. 2005a. Pseudolaelia maquijiensis M.Frey, une nouvelle espèce d’Orchidaceae de l'Espírito Santo, Brésil. Richardiana 5(1): 39-45.

Frey, M. 2005b. Pseudolaelia x perimii M.Frey (Orchidaceae), un hybride naturel nouveau de l'Espírito Santo (Brésil). Richardiana 5(3): 158164.

Frey, M. 2005c. Pseudolaelia pavopolitana M.Frey (Orchidaceae), une nouvelle espèce de l'Espírito Santo, Brésil. Richardiana 5(4): 202-209.

Hoehne, F.C. 1934. Nova espécie de Orchidaceae, Schomburgkia vellozicola. Boletim de Agricultura (São Paulo) 34: 620-623.

Holmgren, P.K.; Holmgren, N.H. \& Barnett, L.C. 1990. Index Herbariorum: the herbaria of the world. New York Botanical Garden, New York

IUCN. 2001. IUCN Red list categories and criteria: version 3.1. Cambridge, IUCN Species Survival Commission.
Kollmann, L.J.C.; Fontana, A.P.; Simonelli, M. \& Fraga, C.N. 2007. Capítulo 13: As angiospermas ameaçadas de extinção no Estado do Espírito Santo. Pp. 105-137. In: Simonelli, M. \& Fraga, C.N. (Orgs.). Espécies da Flora Ameaçadas de Extinção no Estado do Espírito Santo. Vitória, IPEMA.

Menini Neto, L. 2011. Sistemática de Pseudolaelia Porto \& Brade (Orchidaceae). Tese de Doutorado, Escola Nacional de Botânica Tropical, Rio de Janeiro.

Menini Neto, L.; van den Berg, C. \& Forzza, R.C. 2011. Lectotypifications in Pseudolaelia (Laeliinae: Orchidaceae). Kew Bulletin 66: 1-4.

Ministério do Meio Ambiente. 2008. Instrução normativa $n^{\circ} 6$ de 23 de setembro de 2008.

Pabst, G.F.J. 1967. Additamenta ad Orchidologiam Brasiliensem IX. Orquídea 29(2): 62-66.

Pabst, G.F.J. 1973. Additamenta ad Orchidologiam Brasiliensem XV. Bradea 1(36): 361-370.

Pabst, G.F.J. 1976. Additamenta ad Orchidologiam Brasiliensem XXI. Bradea 2(12): 65-70.

Porto, P.C. \& Brade, A.C. 1935. Orchidaceae Novae Brasiliensis I. Archivos do Instituto de Biologia Vegetal do Rio de Janeiro 2(2): 207-216.

Ruschi, A. 1946. Orquidáceas novas do estado do Espírito Santo. Descrição de um novo gênero: Renata canaanensis; quatro espécies novas: Bulbophyllum teresenses, Habenaria melloleitonii, H. mayersii, Theodorea guinlei (12 fotos e 8 pranchas em nanquim). Arquivos Públicos do Estado do Espírito Santo 3: 1-56.

Ruschi, A. 1949. Sistemática Botânica e Zoológica. Descrição de uma nova espécie de Orquidácea: Pseudolaelia dutrae (4 fotos e 3 pranchas em nanquim). Boletim do Museu de Biologia Mello. Leitão, Série: Biologia 1: 30-55.

van den Berg, C.; Higgins, W.E.; Dressler, R.L.; Whitten, W.M.; Soto-Arenas, M.A.; Culham, A. \& Chase, M.W. 2000. A phylogenetic analysis of Laeliinae (Orchidaceae) based on sequence data from internal transcribed spacers (ITS) of nuclear ribosomal DNA. Lindleyana 15(2): 96-114.

van den Berg, C.; Higgins, W.E.; Dressler, R.L.; Whitten, W.M.; Soto-Arenas, M. \& Chase, M.W. 2009. A phylogenetic study of Laeliinae (Orchidaceae) based on combined nuclear and plastid DNA sequences. Annals of Botany 104(3): 417-430.

van den Berg, C.; Barros, F.; Singer, R.B.; Azevedo, C.O.; Chiron, G.R.; Smidt, E.C.; Forster, W.; Felix, L.P.; Figueiredo, G.R.G. \& Monteiro, S.H.N. 2009. Orchidaceae. Pp. 299-309. In: Giulietti, A.M.; Rapini, A.; Andrade, M.J.G.; Queiroz, L.P. \& Silva, J.M.C. (Orgs.). Plantas raras do Brasil. Belo Horizonte, Conservação Internacional.

\section{List of specimens}

Anderson, W.R: 35518 (10); Araújo, R.S: s.n. VIC 30750 (12); Assis, A.M.: 578 (12); Barros, F. 607 (10); Belém, R.P.: 1629 (9), 3776 (9); Bicalho, H.D.: s.n. SP 175174 (4); Bis, R.O.: s.n. MBML 35414 (6), MBML 35413 (8); Borba, E.L.: 140 (5), 554 (7); Boudet-Fernandes, H.Q.: 1878 (4), 1927 (8); Brade, A.C.: 13325 (7); Braga, P.I.S.: 1358 (7); Caiafa, A.N.: s.n. CESJ 30123 (7); Campacci, M.A.: 1918 (11), 1959 (2), 1964 (1); Colnago, E.J.: s.n. SP 330906 (8); Cordeiro, I.: CFSC 6541 (5); Costa, F.E.R: s.n. CESJ 57158 (12); Demuner, V.: 1152 (8), 1623 (6), 2203 (12), 2940 (6), 3459 (6), 3474 (12), 3998 (6), 4234 (6); Duarte, A.P.: 13977 (8); Dungs, F.: s.n. HB 52519 (7); Esgario, C.: 20 (4), 55 (4), 65 (6); Fernandes, T.W.L.: s.n. CESJ 57157 (12); Fontana, A.P.: 5 (8), 104 (8), 122 (8), 123 (8), 681 (8), 816 (4), 883 (6), 1150 (4), 1230 (12), 1234 (6), 1542 (8), 1543 (6), 1557 (6), 3387 (8), 3388 (8), 3637 (8), 4831 (6), 5040 (12), 5053 (12); Forzza, R.C.: 617 (10), 794 (12), 6044 (9); Fraga, C.N.: 426 (12), 498 (12), 527 (12), 1155 (4), 1810 (7); Frey, M.: 30 (3), 231 (3), 514 (6), 655 (6), 672 (6), 702 (8), 901 (9);

\footnotetext{
${ }^{1}$ A "sandwich" grant (bolsa sanduiche in Portuguese) is one that provides for part of the work to be done in Brazil and part to be done abroad.
} 
Ghillany, A.: 209 (5); Gomes, C.: s.n. RB 29801 (7); Hatschbach, G.: 40893 (10), 62863 (12); Hoffmann, H.: s.n. HB 63499 (12); Irwin, H.S.: 22541 (10), 27706 (10); Kautsky, R.: 426 (4), 490 (6), 492 (12); Kollmann, L.: 25 (8), 2795 (4), 3621 (8), 3637 (12), 3638 (8), 8707 (4), 10947 (12), 11013 (12), 11696 (4), 11720 (12), 11746 (12); Krieger, L.: s.n. CESJ 6923 (12), s.n. CESJ 14056 (10); Leoni, L.S.: 1813 (7); Lombardi, J.: - 4717 (8), 5181 (4), 5591 (12); Magnago, L.F.S: 804 (12), 862 (6), 1114 (12); Martinelli, G.: 8751 (7); Mello-Silva, R.: 439 (12); Mendes, M.S. - 552 (12); Menezes, N.L.: 815 (10); Menini Neto, L.: 401 (7), 475 (4), 519 (9), 520 (12), 521 (7), 522 (7), 614 (4), 615 (6), $616(4), 622$ (10), 729 (10), 732 (10), 743 (10), 753 (9), 754 (12), 755 (12), 756 (8), 757 (12), 758 (4), 760 (11), 761 (4), 762 (8), 763 (6), 764 (9), 766 (8), 767 (8), 768 (6), 769 (12), 992 (7); Odebrecht, D.B.: s.n. HB 60736 (12); Pansarin, E.R.: 1021 (7); Pereira, M.: 893 (5); Pereira, O.J.: 2043 (12); Pereira, S.V.: 70 (12); Perim, L.: 1022 (12); Pessanha, A.: 4 (12), 18 (12), 19 (12); Pinheiro, F.: 35 (12), 165 (12); Queiroz, L.P.: 7597 (10); Ruschi, A.: 46 (4), 194 (4), 1502 (8), s.n. HB 3871 (4); Sakuragui, C.: CFCR 15090 (12), CFCR 15118 (12), CFCR 15149 (12); Santos, A.K.A.: 652 (10); Seidel, A.: 906 (8), 960 (8); Stehmann, J.R.: s.n. BHCB 28388 (9); Tameirão Neto, E.: 2373 (8); Teixeira, R.L.: s.n. MBML 22562 (8); van den Berg, C.: 1863 (12), 1864 (12), 1865 (12), 1914 (12), 1915 (12); Vinha, P.C.: 1225 (12); Vervloet, R.: 8 (8), 1901 (4); Voll: s.n. RB 26626 (7); Weinberg, B.: 640 (12); No collector: RB 426398 (7), SP 24567 (12), HB 18964 (12), VIES 12571 (12). 